\title{
Hyperpolarization-activated and cyclic nucleotide-gated channels are differentially expressed in juxtaglomerular cells in the olfactory bulb of mice
}

\author{
Hans-Ulrich Fried • U. Benjamin Kaupp • Frank Müller
}

Received: 16 April 2009 /Accepted: 30 October 2009 / Published online: 6 February 2010

(C) The Author(s) 2010. This article is published with open access at Springerlink.com

\begin{abstract}
In the olfactory bulb, input from olfactory receptor neurons is processed by neuronal networks before it is relayed to higher brain regions. In many neurons, hyperpolarization-activated and cyclic nucleotide-gated $(\mathrm{HCN})$ channels generate and control oscillations of the membrane potential. Oscillations also appear crucial for information processing in the olfactory bulb. Four channel isoforms exist (HCN1-HCN4) that can form homo- or heteromers. Here, we describe the expression pattern of $\mathrm{HCN}$ isoforms in the olfactory bulb of mice by using a novel and comprehensive set of antibodies against all four isoforms. $\mathrm{HCN}$ isoforms are abundantly expressed in the olfactory bulb. HCN channels can be detected in most cell populations identified by commonly used marker antibodies. The combination of staining with marker and $\mathrm{HCN}$ antibodies has revealed at least 17 different staining patterns in juxtaglomerular cells. Furthermore, $\mathrm{HCN}$ isoforms give rise to an unexpected wealth of co-expression patterns but are rarely expressed in the same combination and at the same
\end{abstract}

Electronic supplementary material The online version of this article (doi:10.1007/s00441-009-0904-9) contains supplementary material, which is available to authorized users.

H.-U. Fried $(\bowtie) \cdot$ U. B. Kaupp

Abteilung Molekulare Neurosensorik,

Center of Advanced European Studies and Research,

Ludwig-Erhard-Allee 2,

53175 Bonn, Germany

e-mail: hans.fried@caesar.de

H.-U. Fried • U. B. Kaupp • F. Müller

Institut für Strukturbiologie und Biophysik, ISB-1,

Forschungszentrum Jülich,

52425 Jülich, Germany level in two given cell populations. Therefore, heteromeric $\mathrm{HCN}$ channels may exist in several cell populations in vivo. Our results suggest that $\mathrm{HCN}$ channels play an important role in olfactory information processing. The staining patterns are consistent with the possibility that both homomeric and heteromeric $\mathrm{HCN}$ channels are involved in oscillations of the membrane potential of juxtaglomerular cells.

Keywords Juxtaglomerular cells · Hyperpolarizationactivated and cyclic nucleotide-gated channels · Olfactory bulb · Co-localization · Glomerular layer .

Mouse (C57BL/6N@Rj)

\section{Introduction}

The olfactory bulb is the first relay station of the olfactory system in the brain. Here, olfactory receptor neurons (ORN) are synaptically connected to interneurons and to mitral and tufted cells that project to higher cortical areas. The synapses between ORNs, interneurons, and mitral/ tufted cells are localized to spherical neuropil structures the glomeruli. Glomeruli are surrounded by a heterogeneous population of neurons that, by morphological criteria, fall into three classes: periglomerular (PG) cells, short axon (SA) cells, and external tufted (ET) cells (Kosaka et al. 1998; Pinching and Powell 1971). Collectively, these cells have been termed juxtaglomerular cells. Immunohistochemical studies suggest that juxtaglomerular cells can be grouped into many subpopulations (Kosaka et al. 1998). However, the entire repertoire of juxtaglomerular cells, their specific function, and their electrophysiological properties are largely unknown. 
Juxtaglomerular cells form connections within and between glomeruli, providing the basis for the processing of odor information. Within glomeruli, ORNs provide excitatory input to PG, ET, and mitral/tufted cells. PG cells form inhibitory synapses with ORNs, ET, and mitral/tufted cells, whereas ET cells are excitatory to PG cells (for a detailed review of different circuits within glomeruli, see Wachowiak and Shipley 2006). Connections between glomeruli involve ET, PG, and SA cells (Pinching and Powell 1972). A prominent, yet controversial, model of an interglomerular circuit describes a network for the so-called center-surround inhibition (Aungst et al. 2003; Kosaka et al. 2008). In this model, SA cells receive excitatory input from ET cells and, in turn, excite PG cells that are up to 30 glomeruli away. These PG cells inhibit mitral/tufted cells. Thereby, the activity of ORNs through the successive activation of ET, SA, and PG cells finally inhibits the mitral/tufted cells of neighboring glomeruli.

Rhythmic electrical activity that is either intrinsic or produced by odors is essential for olfactory information processing (Adrian 1950; Fletcher et al. 2005; Hayar et al. 2004a, 2004b; Macrides and Chorover 1972; Margrie and Schaefer 2003; Nusser et al. 2001; Stopfer and Laurent 1999; Walsh 1956). In heart and brain, hyperpolarizationactivated and cyclic-nucleotide-gated ( $\mathrm{HCN})$ ion channels control synchronized network activity (Bender et al. 2005; Luthi and McCormick 1998b; Bal and McCormick 1997), oscillations (Lüthi and McCormick 1998a; Ludwig et al. 2003; Stieber et al. 2003), and temporal integration of synaptic activity in dendrites (Magee 1998; Magee and Carruth 1999; Angelo et al. 2007). HCN channels may also sustain rhythmic activity in the olfactory bulb (Liu and Shipley 2008). The four HCN channel isoforms (HCN1HCN4) differ in their activation kinetics and modulation by cAMP (Kaupp and Seifert 2001; Stieber et al. 2005). The physiological role of HCN channels depends on their density and subcellular localization (Berger et al. 2001; Day et al. 2005; Magee 1998; Magee and Carruth 1999). Moreover, the heteromerization of HCN channel isoforms has been proposed as a mechanism to enhance functional diversity. Although HCN channels, when heterologously expressed, form heteromers (Chen et al. 2001; Much et al. 2003; Ulens and Tytgat 2001), little is known about the existence and functional significance of heteromers in native tissue (Whitaker et al. 2007).

In situ hybridization and initial immunohistochemical studies suggest strong expression of all four HCN channel isoforms in the olfactory bulb of mouse and rat (Notomi and Shigemoto 2004; Santoro et al. 2000; Holderith et al. 2003). However, neither the expression of $\mathrm{HCN}$ isoforms at the single-cell level, nor any patterns of co-expression have been analyzed in depth. We have examined the distribution of all four HCN channel isoforms in the glomerular layer of mouse by using specific antibodies. We have observed abundant expression of all four $\mathrm{HCN}$ isoforms. $\mathrm{HCN}$ channels are present in most populations of juxtaglomerular cells identified by commonly used marker antibodies. Several of these cell populations express two or three HCN isoforms. Our results support the notion of a large variety of juxtaglomerular cell populations and provide the basis for a better understanding of rhythmic electrical activity in the olfactory bulb.

\section{Materials and methods}

Animals

Adult mice (C57BL/6N@Rj; Elevage Janvier France) were used. All procedures were approved by the local animal care committee.

\section{Antibodies against HCN channels}

Antibody production has been described elsewhere (Mataruga et al. 2007; Müller et al. 2003). In brief, for the rat monoclonal antibodies RTQ-7C3, QQA-1A6, and TLL-6C5, peptides used to produce antibodies consisted of seven N-terminal amino acids (aa; CGSSHHH), followed by 35 aa specific for a given $\mathrm{HCN}$ channel isoform (RTQ-7C3: aa sequence 650-685 of rat HCN1; QQA-1A6: aa sequence 699-734 of human HCN2; TLL-6C5: aa sequence $640-675$ of rat HCN3). The guinea pig polyclonal antibodies $\mathrm{HCN} 4 \gamma$ and $\mathrm{HCN} 2 \beta$, the rat monoclonal antibody PG2-1A4 (HCN4), and the rabbit polyclonal antibodies $\mathrm{HCN} 2 \alpha$ and $\mathrm{HCN} 3 \alpha 4$ were obtained after immunization with a glutathione S-transferase fusion protein: the $\mathrm{HCN} 2$ fusion protein contained mouse $\mathrm{HCN} 2$ aa sequence 798-863, the HCN3 fusion protein contained mouse HCN3 aa sequence 718-779, and the HCN4 fusion protein contained mouse HCN4 aa sequence 1116-1201. For generation of the guinea pig polyclonal antibody $\mathrm{HCN} 1 \alpha$, a keyhole limpet hemocyanin fusion protein containing aa sequence 1-18 of mouse $\mathrm{HCN} 1$ was used. We chose antigenic sequences of mouse $\mathrm{HCN}$ channels similar to those used by Notomi and Shigemoto (2004) for the generation of $\mathrm{HCN} 2 \alpha, \mathrm{HCN} 2 \beta, \mathrm{HCN} 3 \alpha 4, \mathrm{HCN} 4 \gamma$, and PG2-1A4 antibodies. Immunization of rabbits and guinea pigs (Pineda Antibody Service, Berlin, Germany; Peptide Specialty Laboratories, Heidelberg, Germany) and the generation of monoclonal antibodies (E. Kremmer, Institute for Molecular Immunology, Helmholtz Zentrum, Munich, Germany) were performed according to standard procedures. To minimize crossreactivity, $\mathrm{HCN} 2 \alpha, \mathrm{HCN} 2 \beta$, and $\mathrm{HCN} 3 \alpha 4$ were purified by affinity chromatography with a fusion protein of the $\mathrm{HCN}$ channel sequences used for immunization and the maltose-binding protein coupled to cyan-bromide-activated 
Sepharose 4B (Amersham Pharmacia Biotech, Freiburg, Germany).

SDS-polyacrylamide gel electrophoresis and Western blot analysis

Isolation of membranes and cytosolic proteins of the olfactory bulb of mouse, SDS-polyacrylamide gel electrophoresis (SDS-PAGE), and Western blot analysis were performed as described by Müller et al. (2003). Proteins (12 $\mu \mathrm{g}$ per lane) were separated on a $10 \%$ SDS-polyacrylamide gel and electrotransferred onto a polyvinylidene difluoride filter. Primary antibodies were RTQ-7C3 (HCN1), $\mathrm{HCN} 2 \alpha$, $\mathrm{HCN} 3$, and $\mathrm{HCN} 4 \gamma$ (dilutions: 1:3, 1:1000, 1:6000, and 1:400, respectively). Secondary antibodies conjugated to horseradish peroxidase were: goat anti-rat IgG (for RTQ-7C3; 1:5000; Jackson ImmunoResearch Laboratories, West Grove, USA), goat anti-rabbit $\operatorname{IgG}$ (for $\mathrm{HCN} 2 \alpha$ and $\mathrm{HCN} 3 ; 1: 5000$; Amersham, Ilford, England), and goat anti-guinea pig IgG (for HCN4 $\gamma$; 1:5000; Santa Cruz Biotechnology, Santa Cruz, USA).

\section{Immunohistochemistry}

Mice ( $n=13 ; \sim 2$ months old) were fixed by intracardial perfusion of ice-cooled $0.9 \% \mathrm{NaCl}$ solution followed by $4 \%$ paraformaldehyde (PFA) and 15\% saturated picric acid in $0.15 \mathrm{M}$ phosphate buffer (PB). Brains were removed, postfixed for $0.5 \mathrm{~h}$, rinsed with $\mathrm{PB}$, and incubated in $10 \%$ sucrose in $\mathrm{PB}$ with $0.05 \% \mathrm{NaN}_{3}$ for $1 \mathrm{~h}$, followed by $30 \%$ sucrose in $\mathrm{PB}$ with $0.05 \% \mathrm{NaN}_{3}$ for $48 \mathrm{~h}$. Olfactory bulbs were embedded and frozen in OCT compound. Coronal sections (20 $\mu \mathrm{m}$ thick) were cut on a cryostat and collected on Superfrost Plus slides (Menzel, Braunschweig, Germany). Only glomeruli at the medial aspect of sections through the middle part of the olfactory bulb were analyzed.

Sections were preincubated for $1 \mathrm{~h}$ in $5 \%$ chemiblocker (Chemicon International, Temecula, USA), $0.5 \%$ Triton $\mathrm{X}-100$, and $0.05 \% \mathrm{NaN}_{3}$ in $\mathrm{PB}$, followed by incubation overnight with primary antibodies diluted in the same solution. Sections were washed in PB and incubated in secondary antibodies diluted in 5\% chemiblocker with $0.5 \%$ Triton X-100 in PB for $1 \mathrm{~h}$, washed in PB, and cover-slipped with Aqua Polymount (Polysciences Europe, Eppelheim, Germany). Primary antibodies were as described in Table 1. Secondary antibodies were donkey anti-guinea pig Cy2 (1:400), donkey anti-guinea pig Cy3 (1:800), donkey antiguinea pig Cy5 (1:800), goat anti-mouse Alexa488 (1:500), donkey anti-mouse Cy3 (1:100), donkey anti-mouse Cy5 (1:100), goat anti-rabbit Alexa488 (1:500), donkey antirabbit Cy3 (1:500), donkey anti-rabbit Cy5 (1:100), goat anti-rabbit Alexa488 (1:500), and donkey anti-rat Cy3 (1:500). Donkey antibodies were purchased from Dianova
(Hamburg, Germany) and goat antibodies from Molecular Probes (Invitrogen, Karlsruhe, Germany). For double- or triple-labeling, primary antibodies generated in different species were mixed and applied simultaneously. All secondary antibodies were highly cross-absorbed and were tested to exclude reactions with the wrong primary antibody.

In some experiments, staining was performed with two antibodies generated in the same species. This was possible only if the two antibodies stained different cell compartments, e.g., the soma membrane and the cytosol. Two cases could be distinguished. (1) Antibodies stained different compartments in different cells. In this case, the two antibodies were detected with the same secondary antibody. Staining, whereby each primary antibody was applied alone, were used as a reference to distinguish between the staining of the two antibodies. (2) Antibodies stained different compartments in the same cell. In this case, staining patterns were distinguished by using a technique described by Vardi et al. (2000). This technique involved the use of Fab fragments to block one of the antibodies produced in the same species. Here, we used the technique only for some staining with $\mathrm{HCN} 3$ antibodies. In brief, sections were incubated with rabbit anti-HCN3 overnight, washed in PB, incubated with goat anti-rabbit Fab fragments conjugated to Cy3 (1:1000; Dianova, Hamburg, Germany) for $1 \mathrm{~h}$, washed in $\mathrm{PB}$, incubated with a rabbit anti-marker antibody (twice as concentrated as given in Table 1) for $1 \mathrm{~h}$, washed in PB, and finally incubated with donkey anti-rabbit Cy5 or goat anti-rabbit Alexa488 as described above. Control experiments in which anti-marker antibodies were omitted displayed no Cy5 or Alexa488 staining. Furthermore, stringent internal controls were included in each staining; the strong staining resulting from one primary antibody was not detected by the secondary antibody used for the other primary antibody. In addition, all staining of a primary antibody was similar, irrespective of whether it had been used alone or in combination with another primary antibody raised in the same species.

Sections were examined with a Leica TCS confocal laser scanning microscope (LSM, Leica Microsystems Germany) with $20 \times / 0.7$ and $63 \times / 1.32$ oil immersion lenses. The contrast and brightness of the images were optimized in Adobe Photoshop. Laser intensity and filter settings were carefully controlled, and the sequential scanning mode was employed to rule out cross-talk between the fluorescence detection channels completely. Band pass filters of $500-530 \mathrm{~nm}$ for green fluorescence (Alexa488, Cy2), 580-650 nm for red fluorescence $(\mathrm{Cy} 3)$, and $680-750 \mathrm{~nm}$ for infra-red fluorescence (Cy5) were used.

Cells were classified as PG-, SA-, or ET-like by several independent expert observers. The observers classified large numbers of cells comprising all 17 different immunohistochemical fingerprints (IFs) on z-stacks (examples of recon- 


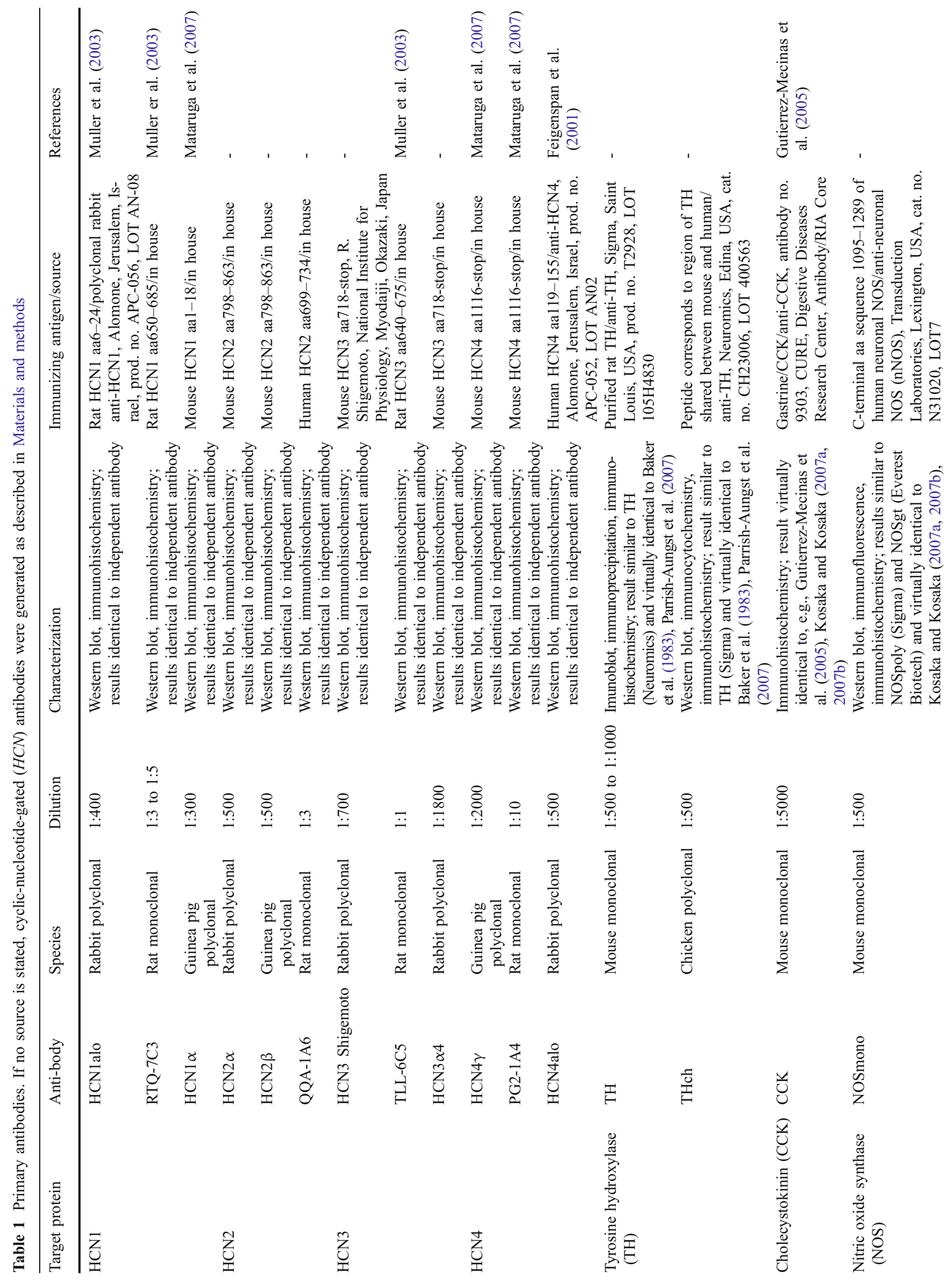



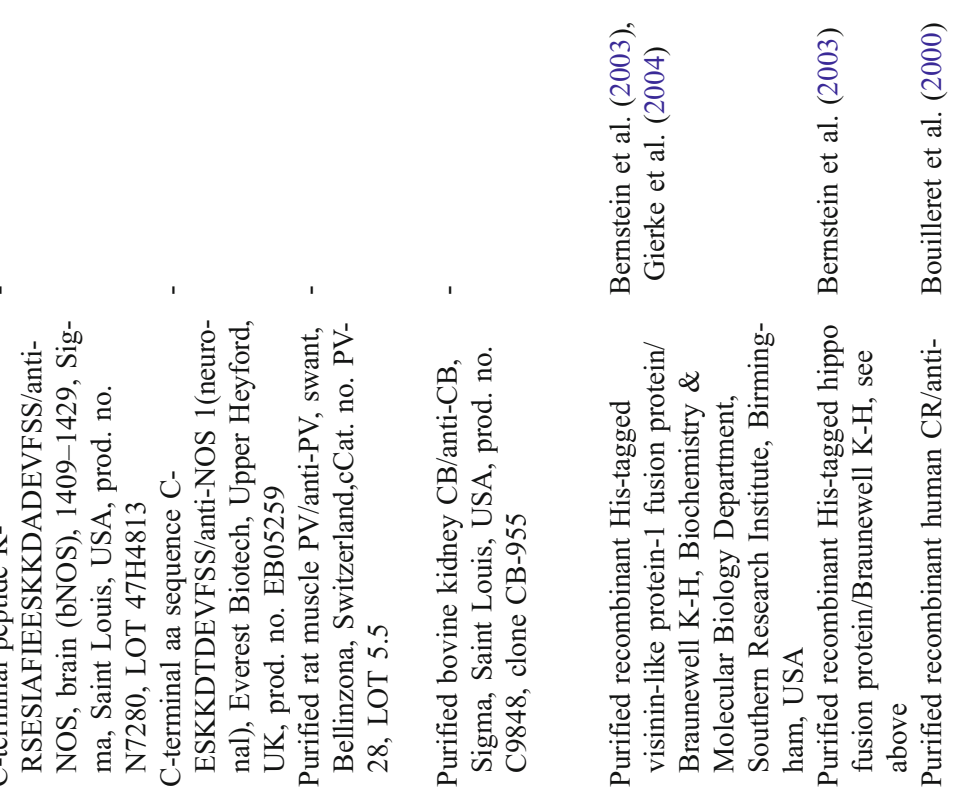

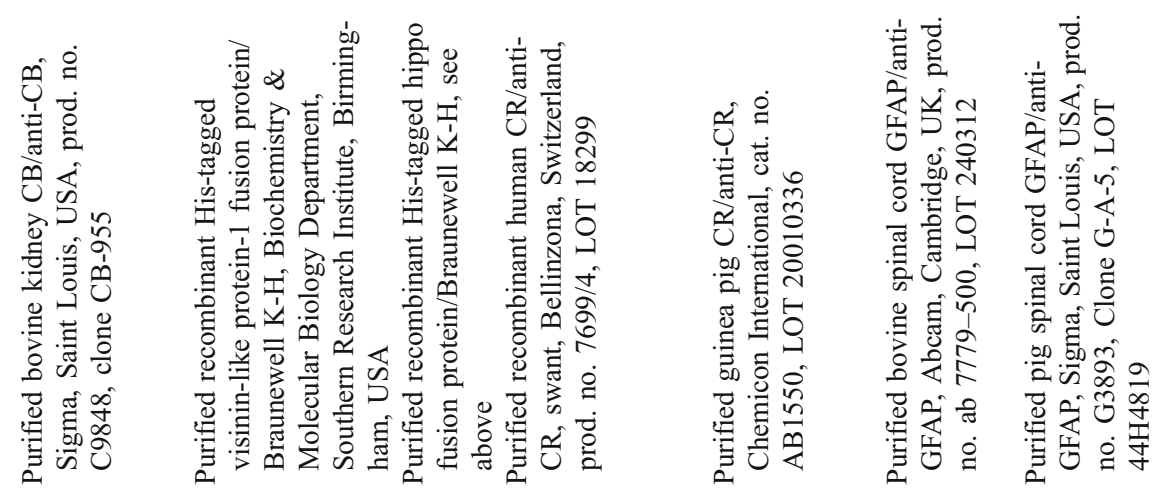

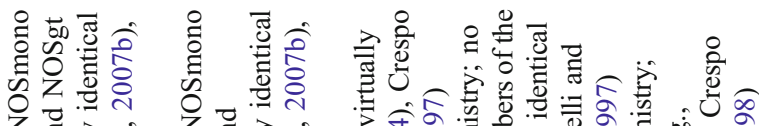

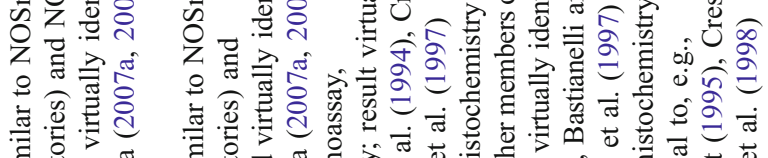

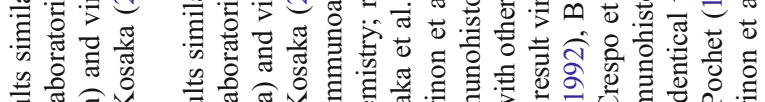

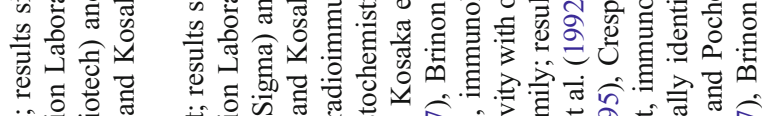
Whing Whe

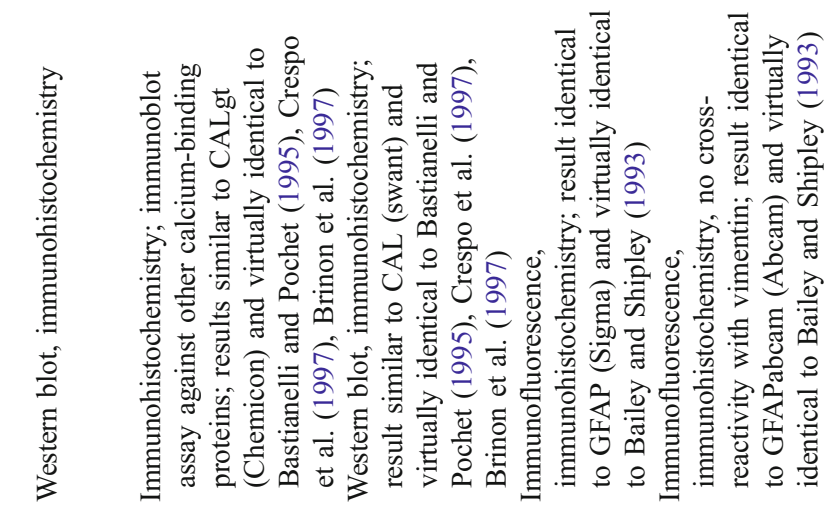

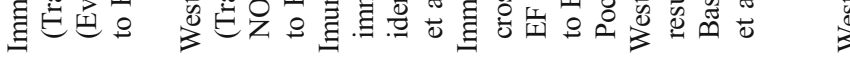

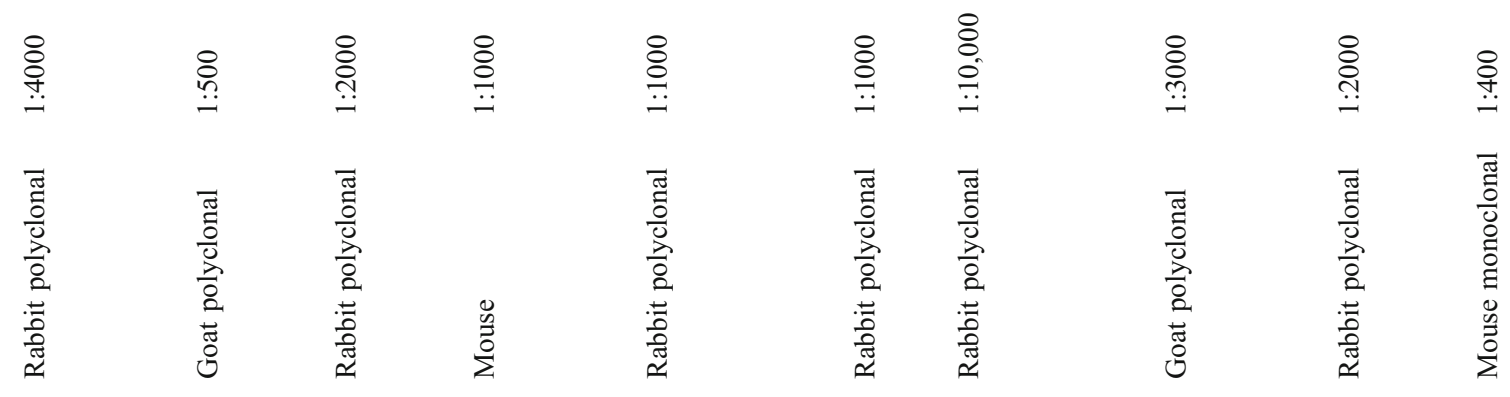

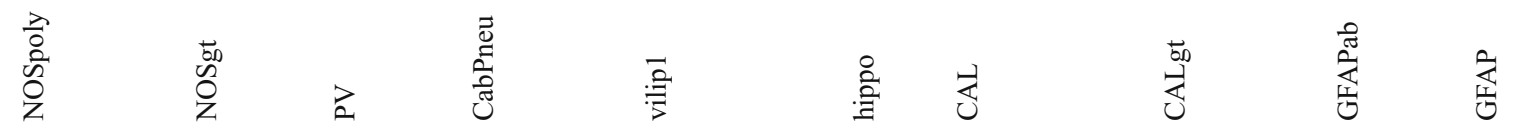

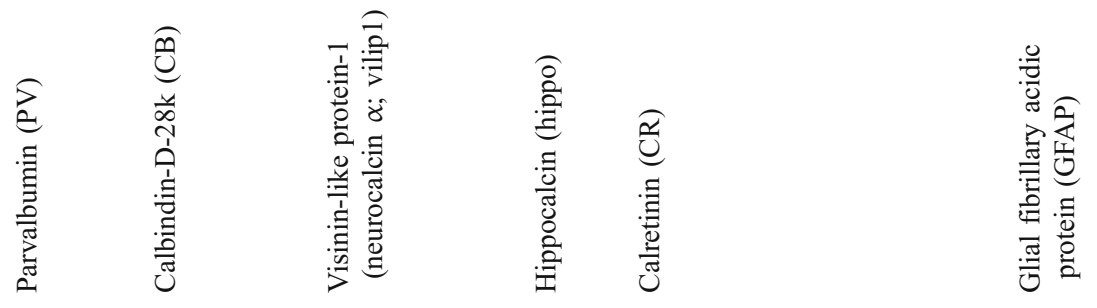


structed cells are shown below and in the Electronic Supplementary Material) or by visual inspection of staining at the microscope. PG-, SA-, and ET-like cells were identified on the basis of morphological criteria. PG cells are neurons with small somata and usually one or two dendrites that ramify extensively in a single (sometimes two) neighboring glomeruli. In contrast, SA cells are larger than most PG cells. Often, SA cells have more than two dendrites that do not ramify in glomeruli but rather reach across several adjacent glomeruli to contact other juxtaglomerular cells. ET cells display large somata and usually possess one thick primary tuft that ramifies within a single glomerulus. Some ET cells additionally possess far-reaching lateral dendrites (Pinching and Powell 1971). Only cells that could clearly be classified by these criteria are shown in the figures and have been included in the analyses summarized in Tables 2, 3 (excluding frequency of cell types, see below). We did not use criteria other than the presence/absence of thick primary tufts and presence/absence of $\mathrm{HCN}$ and marker stainings to establish IFs (see Electronic Supplementary Material).

\section{Measurement of somata size and frequency of cell types}

To quantify cell size, we measured the circumference of cells in confocal sections and calculated cell diameters by assuming a circular shape. In confocal sections, almost spherical cells can be cut at levels other than that yielding the maximal cell diameter. To avoid an under-estimation of the cell size, many somata of identified cells were analyzed, and only the largest third was used for the calculation of soma size. For frequent cell populations (cells with IF1, IF2, IF6, IF7, IF8, or IF9), we measured the circumferences of 40-61 individual cells, and for rare cell types (cells with IF3, IF4, IF5, IF10, IF11, IF12, IF13, IF14, IF15, IF16, or IF17), we measured the circumferences of 31-45 individual cells ( $n \geq$ three animals each). Numbers are given as means \pm SD. This method allows the analysis of large amounts of data sets, albeit with considerable error. To demonstrate that, for the present study, the error was within a tolerable range, we reconstructed cells in three dimensions (3D; Imaris software, Bitplane, Zürich, Switzerland, see Electronic Supplementary Material) and calculated cell diameters as described above. We reconstructed $10 \mathrm{CB}-$ stained and $10 \mathrm{CR}$-stained PG-like cells and calculated mean diameters of $7.9 \pm 0.4 \mu \mathrm{m}$ and $6.7 \pm 0.5 \mu \mathrm{m}$, respectively. Using circumferences of the largest third, we calculated, for the $\mathrm{CB}$ and $\mathrm{CR}$ cell population, mean diameters of $7.9 \pm 0.8 \mu \mathrm{m}$ and $6.5 \pm 0.8 \mu \mathrm{m}$, respectively. We also reconstructed ET-like cells (six NOS-stained and seven vilip1-stained cells) and calculated mean diameters of $11.5 \pm 0.6 \mu \mathrm{m}$ and $10.8 \pm 0.4 \mu \mathrm{m}$, respectively (compared with $12.2 \pm 2 \mu \mathrm{m}$ and $11.6 \pm 2 \mu \mathrm{m}$ by using the circum- ferences of the largest third, respectively). Thus, both methods yielded similar results.

To estimate the frequencies at which different populations of juxtaglomerular cells occurred per glomerulus, we counted cells of a particular population in the neighborhood of many adjacent glomeruli in several confocal sections ( $n \geq$ three animals per cell type, see Electronic Supplementary Material, Table 1). Staining used to count the various populations were (for antibodies see Table 1) HCN1/NOS (IF1), HCN1/HCN4/CB (IF1, IF2, IF5, and IF6), PV (IF4), TH/CAL/NOS (IF7, IF8, IF9, IF16, and IF17), NOS (IF10), HCN2 (IF11), HCN1/HCN4/NOS (IF12 and IF13), vilip1 (IF14), HCN1/CCK/NOS, and HCN4/NOS/TH (IF15). To estimate the frequency of cells with IF3, we counted all vilip1-positive PG-like cells and subtracted the number of PV-positive (IF4) cells.

The counting relied on four assumptions. (1) Somata and glomeruli are spherical. (2) All planes of a glomerulus are equally represented provided a sufficient number of confocal sections are analyzed. (3) All cells of a particular population can be readily identified in a confocal section; this assumption is expected not to be met completely, because the diameter of some cells in a confocal section will be too small and, therefore, frequencies will be underestimated. (4) All glomeruli contain similar proportions of cell populations. Ideally, the number of a given cell type per glomerulus, the frequency, can be determined by counting all cells of this type along an entire glomerulus in an extremely thick section. We derived the frequencies according to:

Frequency $=\frac{\mathrm{d}_{\text {glom }} C}{\mathrm{~d}_{\text {celltype }} n_{\text {glom }}}$

Cells of a given type were counted (number of counted cells $=$ C) in confocal sections across many adjacent glomeruli (number of glomeruli $=n_{\text {glom }}$ ) and expressed as cell numbers per section and glomerulus $\left(C / n_{\text {glom }}\right)$. To derive the frequency per whole glomerulus, $C / n_{\text {glom }}$ was multiplied with the frequency that this cell type can be found along the $\mathrm{Z}$-axis of a glomerulus. This measure can be expressed as $d_{\text {glom }} / d_{\text {celltype }}$, the ratio of the diameter of a standard glomerulus $\left(d_{\text {glom }}=100 \mu \mathrm{m}\right.$; see Royet et al. 1988) and the mean diameter of the cell soma $\left(d_{\text {celltype }}\right)$. To demonstrate the general applicability of the method, we determined the total cell number surrounding a standard glomerulus with a nuclear stain (TOPRO-3, Molecular Probes) and compared the result with published numbers established by the optical dissector method (Parrish-Aungst et al. 2007).

Statistical analysis was performed with Microsoft Excel and Mathlab. Similarity between the soma diameters of the different cell populations was analyzed by using a pair-wise Kruskal-Wallis test with all possible combinations. 


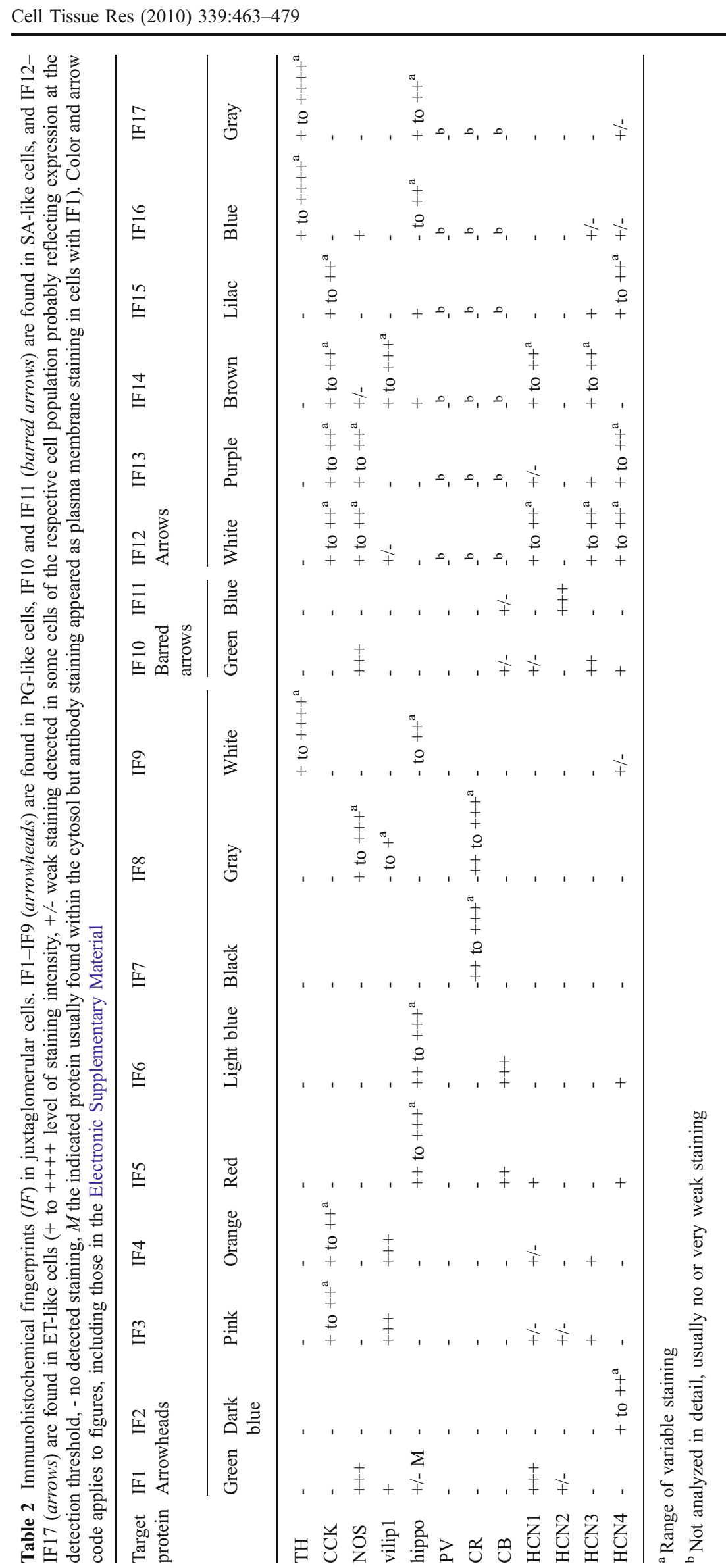

으 Springer 
Table 3 Properties of cells with a particular immunohistochemical fingerprint ( $P G$ periglomerular cells, $S A$ short axon cells, ET external tufted cells, $n . d$. not determined)

\begin{tabular}{|c|c|c|c|c|}
\hline $\begin{array}{l}\text { Immunohistochemical } \\
\text { fingerprint (IF) }\end{array}$ & $\operatorname{Diameter}^{\mathrm{a}}(\mu \mathrm{m})$ & $\begin{array}{l}\text { Number of cells per } \\
\text { glomerulus section }\end{array}$ & $\begin{array}{l}\text { Number of cells } \\
\text { per glomerulus }\end{array}$ & $\begin{array}{l}\text { Number of dendrites (for } \mathrm{PG}+\mathrm{SA} \text { ) } \\
\text { or presence of stained lateral } \\
\text { dendrites (for ET) }\end{array}$ \\
\hline IF1 & $7.1 \pm 0.6$ & $2.1 \pm 0.3$ & $28.9 \pm 5.1$ & 1 \\
\hline IF2 & $7.8 \pm 1.0$ & $2.0 \pm 0.1$ & $25.0 \pm 3.3$ & 1 \\
\hline IF3 & $9.1 \pm 0.7$ & $0.7 \pm 0.4$ & $7.2 \pm 3.3$ & $\geq 2$ \\
\hline IF4 & $8.6 \pm 0.8$ & $1.2 \pm 0.1$ & $13.4 \pm 1.9$ & $\geq 2$ \\
\hline IF5 & $8.0 \pm 0.7$ & $1.0 \pm 0.3$ & $12.6 \pm 4.1$ & $1^{\mathrm{b}}$ \\
\hline IF6 & $7.8 \pm 0.9$ & $1.4 \pm 0.3$ & $17.4 \pm 4.7$ & $1^{\mathrm{b}}$ \\
\hline IF7 & $6.5 \pm 0.8$ & $4.3 \pm 0.3$ & $66.3 \pm 9.5$ & $1^{\mathrm{b}}$ \\
\hline IF8 & $6.5 \pm 0.9$ & $4.3 \pm 1.1$ & $66.3 \pm 19.5$ & $1^{\mathrm{b}}$ \\
\hline IF9 & $7.7 \pm 1.2$ & $2.3 \pm 0.4$ & $29.5 \pm 6.8$ & n.d. \\
\hline IF10 & $9.4 \pm 1.1$ & $0.4 \pm 0.1$ & $4.0 \pm 0.5$ & $\geq 2$ \\
\hline IF11 & $8.9 \pm 0.7$ & $0.4 \pm 0.1$ & $4.7 \pm 0.9$ & $\geq 3$ \\
\hline IF12 & $12.1 \pm 1.8$ & $0.7 \pm 0.5$ & $6.0 \pm 3.8$ & Yes \\
\hline IF13 & $12.3 \pm 2.1$ & $0.5 \pm 0.2$ & $4.0 \pm 2.1$ & Yes \\
\hline IF 14 & $11.6 \pm 2.0$ & $0.9 \pm 0.3$ & $7.8 \pm 2.7$ & No \\
\hline IF15 & $12.2 \pm 1.8$ & $0.6 \pm 0.1$ & $4.8 \pm 0.9$ & Yes \\
\hline IF16 & $12.6 \pm 1.9$ & $0.3 \pm 0.1$ & $2.1 \pm 0.5$ & No \\
\hline IF17 & $12.0 \pm 1.4$ & $0.9 \pm 0.3$ & $7.4 \pm 2.7$ & No \\
\hline TOPRO (nuclear stain) & $6.6 \pm 1.1$ & $46.5 \pm 4.5$ & $705 \pm 136$ & - \\
\hline
\end{tabular}

${ }^{\mathrm{a}} \mathrm{Mean} \pm \mathrm{SD}$

${ }^{\mathrm{b}}$ In rare cases, 2

\section{Results}

Distribution of HCN channel isoforms in the olfactory bulb

The distribution of HCN channels in the olfactory bulb was examined with 12 different antibodies against the four HCN channel isoforms (Table 1). Each HCN isoform was recognized by three antibodies generated in different species. In addition, for each $\mathrm{HCN}$ isoform, two antibodies were generated against different epitopes. The specificity and suitability of antibodies was ensured by three criteria. (1) Western blots of proteins from olfactory bulb and from HEK 293 cells that expressed either one of the four HCN isoforms. After treatment with PNGaseF to remove protein glycosylation, the antibodies recognized proteins of the expected molecular weight of 102, 94, 86, and $130 \mathrm{kDa}$ for $\mathrm{HCN} 1, \mathrm{HCN} 2, \mathrm{HCN} 3$, and $\mathrm{HCN} 4$, respectively (Fig. 1a; Müller et al. 2003). (2) Independent antibodies directed against the same $\mathrm{HCN}$ isoform produced identical staining patterns as demonstrated by the superposition of images (Fig. 1b, c, Electronic Supplementary Material, Fig. 1). (3) In HCN1 and HCN3 knockout animals, no staining was observed with antibodies against the deleted isoform (Electronic Supplementary Material, Fig. 2; HCN1 knockout mice: Nolan et al. 2003; HCN3 knockout mice: gift of Martin Biel, Ludwig-Maximilians Universität, Munich, Germany).

Each $\mathrm{HCN}$ isoform showed a characteristic expression pattern in the various layers of the olfactory bulb (Fig. 1c, $\mathrm{e}-\mathrm{g})$. The HCN staining originated from somata and neuronal processes alike. Each $\mathrm{HCN}$ isoform was found only in subsets of cells. Therefore, staining intensities differed between different layers. HCN1 was strongly expressed in the glomerular layer (GL), followed by some weaker expression in the internal plexiform layer (IPL) and the granule cell layer (GrL). Only weak staining was observed in the external plexiform layer (EPL). For HCN2, the most intense staining was observed in individual cell bodies distributed across all but the olfactory nerve layer (AL). HCN3 was strongly expressed in the IPL and the outer part of the EPL. Strong HCN4 staining was observed in all layers; in the AL, it appeared to be the only $\mathrm{HCN}$ isoform. Thus, in the GL, abundant expression of all four $\mathrm{HCN}$ isoforms was observed. In the following, we restrict our analysis to the GL.

$\mathrm{HCN}$ isoforms are expressed in many different combinations

In the GL, antibodies against all $\mathrm{HCN}$ isoforms stained the somatic and dendritic plasma membrane (Fig. 2). Moreover, 


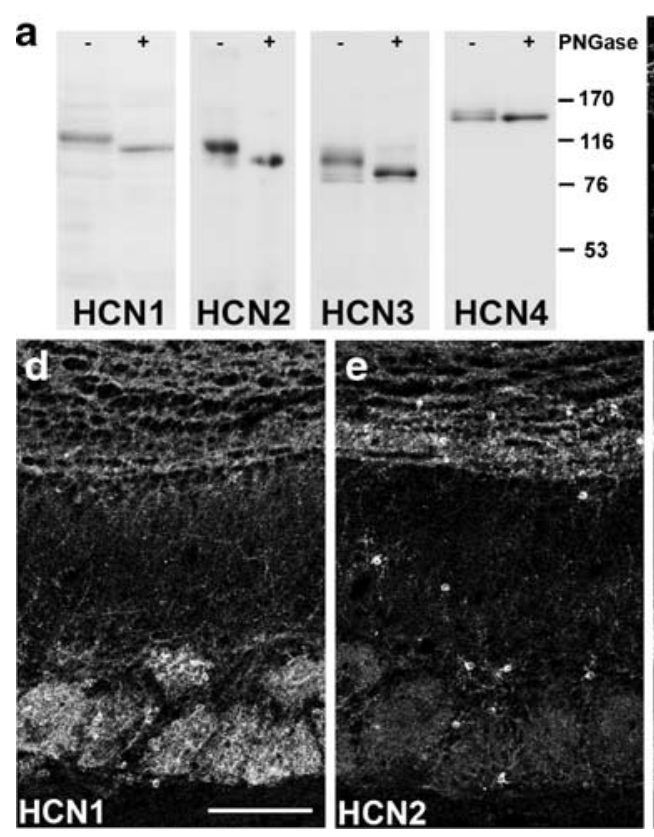

Fig. 1 Survey of HCN channel expression in the olfactory bulb. a Antibodies against HCN1-HCN4 (HCN1 RTQ-7C3, HCN2 HCN2 $\alpha$, $H C N 3$ HCN3 Shigemoto, HCN4 HCN4 $\gamma$ ) recognize the glycosylated and degylcosylated $\mathrm{HCN}$ isoforms in Western blots of proteins from mouse olfactory bulb. The enzyme PNGaseF was used to deglycosylate $\mathrm{HCN}$ channels (+ lanes). Molecular weights of deglycosylated $\mathrm{HCN}$ channels were $102 \mathrm{kDa}(\mathrm{HCN} 1), 94 \mathrm{kDa}(\mathrm{HCN} 2), 86 \mathrm{kDa}$ (HCN3), and $130 \mathrm{kDa}(\mathrm{HCN} 4)$. Comparison of molecular weights with (+ lanes) and without (- lanes) PNGaseF treatment shows that all $\mathrm{HCN}$ isoforms are glycosylated (numbers right molecular weight markers in $\mathrm{kDa}$ ). $\mathbf{b}$, $\mathbf{c}$ Representative example of double-labeling with

the specific glia cell marker GFAP (glial fibrillary acidic protein) did not co-localize with HCN staining, suggesting that the majority of $\mathrm{HCN}$ channels were present in neurons (Electronic Supplementary Material, Fig. 6). Cells stained by $\mathrm{HCN}$ antibodies fell into two groups. The first group was characterized by relatively small somata and thin dendritic processes (Fig. 2e-o). This group comprised both PG and SA cells. The second group displayed large somata and usually possessed only one thick primary tuft, which ramified within a single glomerulus, features characteristic of ET cells (Fig. 2p-s, see also Materials and methods).

Triple- and double-labeling revealed subpopulations of PG- and SA-like cells that expressed either a single HCN isoform or combinations of $\mathrm{HCN}$ isoforms (Fig. 2e-s). Because compelling evidence (staining intensity of + or stronger in Table 2) for the co-expression of HCN2 with the other isoforms was lacking (Fig. 2e-k), triple-staining with $\mathrm{HCN} 1, \mathrm{HCN} 3$, and $\mathrm{HCN} 4$ antibodies was sufficient to reconstruct a complete co-expression pattern of $\mathrm{HCN}$ channels (see Fig. 21-s, Table 2). PG- and SA-like cells were identified that expressed only HCN1 (Fig. 21-o, green arrowheads) or HCN4 (Fig. 2p-s, dark blue arrowheads).
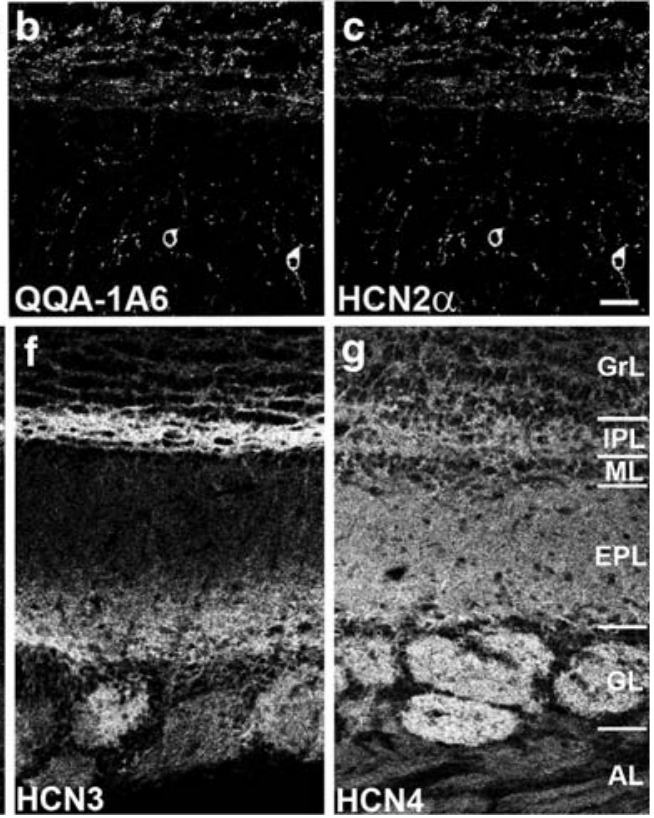

two antibodies (b QQA-1A6, c $\mathrm{HCN} 2 \alpha$ ) that recognize different epitopes of one and the same $\mathrm{HCN}$ isoform (HCN2). The staining patterns produced by the two antibodies are identical. Field of view reaches from the glomerular layer (top) to the external plexiform layer (bottom). Bar $20 \mu \mathrm{m}$. d-g Immunohistochemical staining shows the distribution of $\mathrm{HCN} 1$ (d), $\mathrm{HCN} 2$ (e), $\mathrm{HCN} 3$ (f), and $\mathrm{HCN} 4$ (e) within the various layers of the olfactory bulb in $20-\mu \mathrm{m}$-thick coronal sections ( $E P L$ external plexiform layer, $G L$ glomerular layer, $G r L$ granule cell layer, $I P L$ internal plexiform layer, $M L$ mitral cell layer, $A L$ olfactory nerve layer). Antibodies used were: $\mathrm{HCN} 1 \alpha(\mathbf{d}), \mathrm{QQA}-$ $1 \mathrm{~A} 6$ (e), $\mathrm{HCN} 3 \alpha 4$ (f), PG2-1A4 (g). Bar $100 \mu \mathrm{m}$

Moreover, HCN1 and HCN3 co-localized (Fig. 21-o, orange arrowhead) in one population of cells, and in another, HCN1 and HCN4 were co-localized (Fig. 21-o, red arrowhead). Thus, some cell populations expressed a single $\mathrm{HCN}$ channel isoform only (HCN1, $\mathrm{HCN} 2$, or $\mathrm{HCN} 4)$, whereas others co-expressed $\mathrm{HCN} 1 / 3$ or $\mathrm{HCN} 1 / 4$. Coexpression of $\mathrm{HCN}$ isoforms occurred more often in ET-like cells than in PG- and SA-like cells. The following combinations were observed: $\mathrm{HCN} 1 / 3, \mathrm{HCN} 3 / 4$, and $\mathrm{HCN} 1 / 3 / 4$ (Fig. 2a-d, p-s). This demonstrates, for the first time at the protein level, the expression of three $\mathrm{HCN}$ channel isoforms within the same neuron. Remarkably, in the GL, we could find no convincing evidence for the expression of HCN3 channels alone. Even in the entire main olfactory bulb, exclusive HCN3 staining was rarely observed (see Fig. 2a-d, outer EPL).

Staining patterns in somata and dendritic processes, e.g., the glomerular neuropil (region inside the dashed white outlines of glomeruli in Fig. 2), were similar. Dendrites harboring only $\mathrm{HCN} 1, \mathrm{HCN} 2$, or $\mathrm{HCN} 4$ were common, whereas dendrites expressing only HCN3 were rare. Furthermore, HCN2 by and large was expressed on its own. Co- 

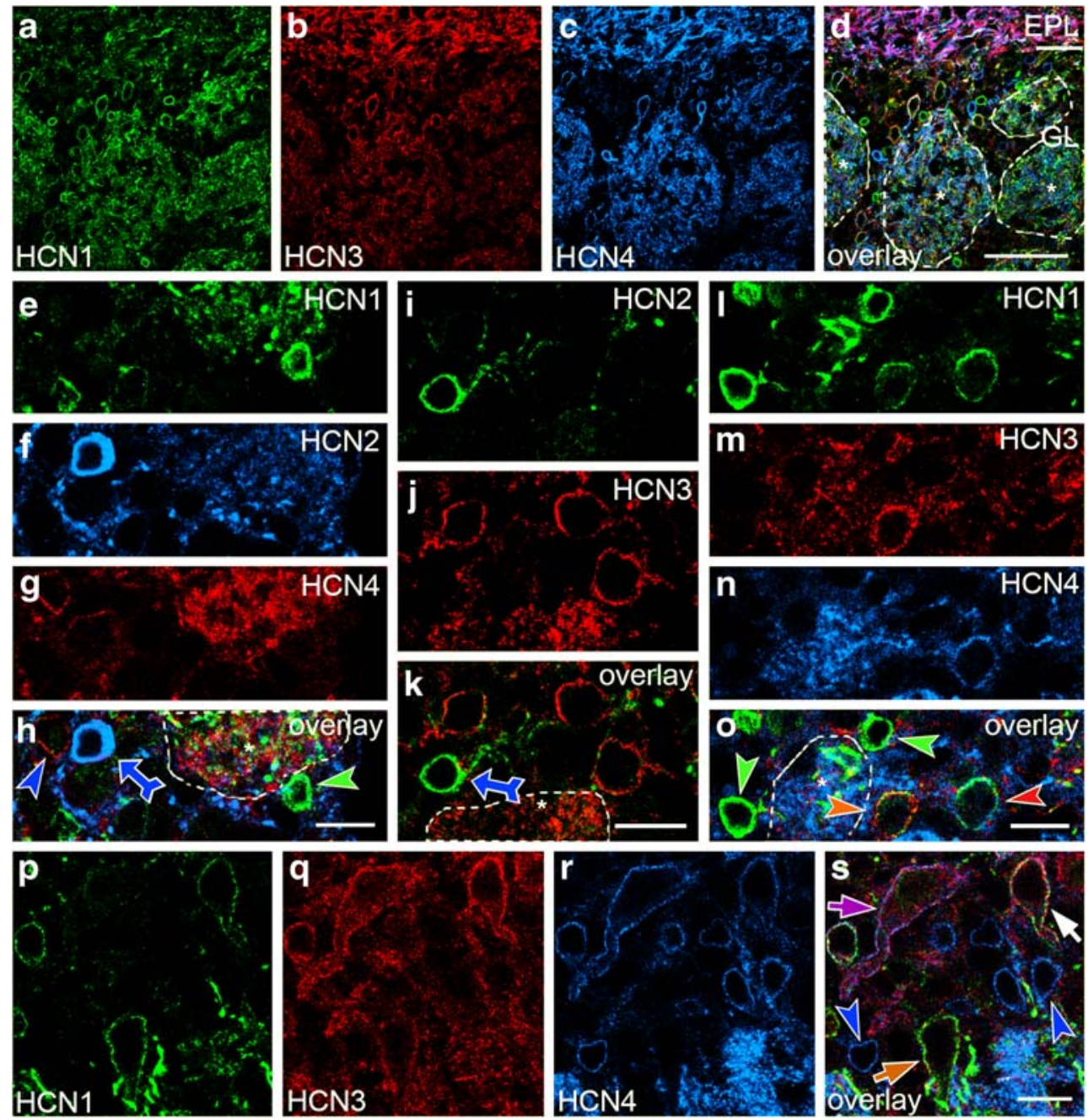

Fig. 2 Localization pattern of $\mathrm{HCN}$ channel isoforms in the glomerular layer. a-d Low magnification of triple-labeling for HCN1 (green, RTQ-7C3), HCN3 (red, HCN3 Shigemoto), and HCN4 (blue, PG2-1A4) in the external plexiform layer $(E P L)$ and glomerular layer $(G L)$. e-o Example of various populations of PGand SA-like cells. Three cell populations express only a single $\mathrm{HCN}$ isoform (overlays in $\mathbf{h}, \mathbf{k}, \mathbf{0}$ : green arrowhead $\mathrm{HCN} 1$, blue barred arrow $\mathrm{HCN} 2$, dark blue arrowhead $\mathrm{HCN} 4)$. This is demonstrated with triple-labeling $(\mathbf{e}-\mathbf{h})$ for $\mathrm{HCN} 1$ (green $\mathrm{HCN} 1 \alpha)$, $\mathrm{HCN} 2$ (blue HCN $2 \alpha$ ), and HCN4 (red PG2-1A4), double-labeling (i-k) for HCN2 (green QQA-1A6) and HCN3 (red HCN3 Shigemoto), and triple-labeling (l-o) for $\mathrm{HCN} 1$ (green $\mathrm{HCN} 1 \alpha$ ), $\mathrm{HCN} 3$ (red $\mathrm{HCN} 3 \alpha 4$ ), and HCN4 (blue PG2-1A4). The cell population expressing only HCN4 is also visible in $\mathbf{s}$ (dark blue arrowheads). Colocalization of either $\mathrm{HCN} 1$ (green $\mathrm{HCN} 1 \alpha$ ) and $\mathrm{HCN} 3$ (red $\mathrm{HCN} 3$ Shigemoto) or HCN1 (green HCN1 $\alpha$ ) and HCN4 (blue PG2-1A4) in

two additional cell populations (orange arrowhead, red arrowhead, respectively) is shown in $\mathbf{o}$. p-s Three ET-like cell populations with different repertoires of $\mathrm{HCN}$ isoforms (white arrow $\mathrm{HCN} 1, \mathrm{HCN} 3$, and $\mathrm{HCN} 4$, orange arrow $\mathrm{HCN} 1$ and $\mathrm{HCN} 3$, purple arrow $\mathrm{HCN} 3$ and $\mathrm{HCN} 4$ ) can be detected in the triple-staining for HCN1 (green HCN $1 \alpha$ ), HCN3 (red HCN3 Shigemoto), and HCN4 (blue PG21A4). PG-like cells expressing only HCN4 are indicated (dark blue arrowheads). From these stainings, it is not apparent which of the cell populations identified in later experiments (Figs. 3, 4, 5) are stained. However, by using the results of all staining performed, one can unequivocally identify the cell types here. For convenience, cell populations in this and the following figures are labeled with the uniform color and arrow code shown in Table 2. Glomeruli are indicated by an asterisk and delineated by a dashed white line. Bars $50 \mu \mathrm{m}(\mathbf{d}), 10 \mu \mathrm{m}(\mathbf{h}, \mathbf{k}, \mathbf{o}, \mathbf{s})$

localization of $\mathrm{HCN} 1, \mathrm{HCN} 3$, and $\mathrm{HCN} 4$ existed in all possible combinations ( $\mathrm{HCN} 1 / 3, \mathrm{HCN} 1 / 4, \mathrm{HCN} 3 / 4$, and HCN1/3/4). Relatively thick dendritic processes in the outer EPL (Fig. 2a-d) showed the co-localization of either HCN3/ 4 (purple dendritic processes in Fig. 2d) or of $\mathrm{HCN} 1 / 3 / 4$ (white dendritic processes in Fig. 2d). By visual inspection of staining, we observed that the thick dendritic processes

originated from the somata of ET-like cells and extended laterally into the EPL. Thus, they probably represented lateral dendrites of at least two different ET cell populations. One ET cell population expressed $\mathrm{HCN} 3 / 4$, whereas another population expressed $\mathrm{HCN} 1 / 3 / 4$.

The rich expression patterns of $\mathrm{HCN}$ channels indicate that many different cell populations exist. In the following, 
we relate $\mathrm{HCN}$ channel expression patterns to previously described cell populations by combining immunostaining for markers and $\mathrm{HCN}$.

Immunohistochemical characterization of juxtaglomerular cells expressing HCN channels

We used antibodies against eight cellular marker proteins to characterize populations of juxtaglomerular cells expressing HCN channels. Seven of these marker proteins, including tyrosine hydroxylase (TH), nitric oxide synthase (NOS), the neuropeptide cholecystokinin (CCK), the calcium-binding proteins visinin-like protein 1 (vilip1; also known as neurocalcin $\alpha$ ), parvalbumin (PV), calretinin (CR), and calbindinD28K (CB), have been previously used to distinguish between subpopulations of juxtaglomerular cells (Baker et al. 1983; Brinon et al. 1992, 1997, 1998; Kosaka et al. 1994; Liu and Shipley 1994; Bastianelli and Pochet 1995; Crespo et al. 1997; Bernstein et al. 2003; Gutierrez-Mecinas et al. 2005; Parrish-Aungst et al. 2007; Kosaka and Kosaka 2007b). In general, the staining patterns that we obtained for these marker proteins were similar to those published. In addition, we employed antibodies against hippocalcin, another calcium-binding protein, which proved useful as another marker to distinguish between different juxtaglomerular cells. To the best of our knowledge, hippocalcin antibodies have not been used before for staining of the olfactory bulb. A lower magnification of a representative hippocalcin staining is shown in Electronic Supplementary Material, Fig. 3. We used marker and HCN channel antibodies in more than 140 combinations. We found highly reproducible co-localization patterns in the different juxtaglomerular cell populations (for details see Electronic
Supplementary Material); these patterns are referred to as IFs in the following.

In many cases, marker antibodies stained cells intensely, thereby revealing even small anatomical details that allowed us to distinguish between populations of PG and SA cells. PG cells are neurons with small somata and usually have one to two dendrites that ramify extensively in a single (sometimes two) neighboring glomeruli. In contrast, SA cells are larger than most PG cells. Often, SA cells have more than two dendrites, which do not ramify in glomeruli (Table 3) but rather reach across several adjacent glomeruli to contact other juxtaglomerular cells (Pinching and Powell 1971).

PG-like cells In PG-like cells, at least nine different IFs were identified (IF1-IF9) that showed multiple expression patterns of HCN channels (Fig. 3, Table 2, Electronic Supplementary Material, Fig. 4). In two IFs, strong staining for one $\mathrm{HCN}$ isoform was present (IF1 and IF2). In four other IFs, moderate staining for either one $\mathrm{HCN}$ isoform (IF6) or several HCN isoforms was observed (IF3-IF5), and the remaining IFs seemed to be devoid of HCN staining (IF7-IF9). A detailed description of IFs found in PG-like cells is given in the Electronic Supplementary Material.

SA-like cells Two IFs were identified in SA-like cell populations (IF10 and IF11). We found strong HCN staining in both IFs. Strong staining for NOS and HCN3, but weak staining for HCN4 was detected in IF10 (Fig. 4b-h, Table 2). Dendrites of cells with the IF10 usually reached across several adjacent glomeruli (Fig. 4a).

IF11 (labeling with HCN2 antibodies only) was found in a second SA-like cell population. The cell type could not be classified unequivocally, because distal dendrites were
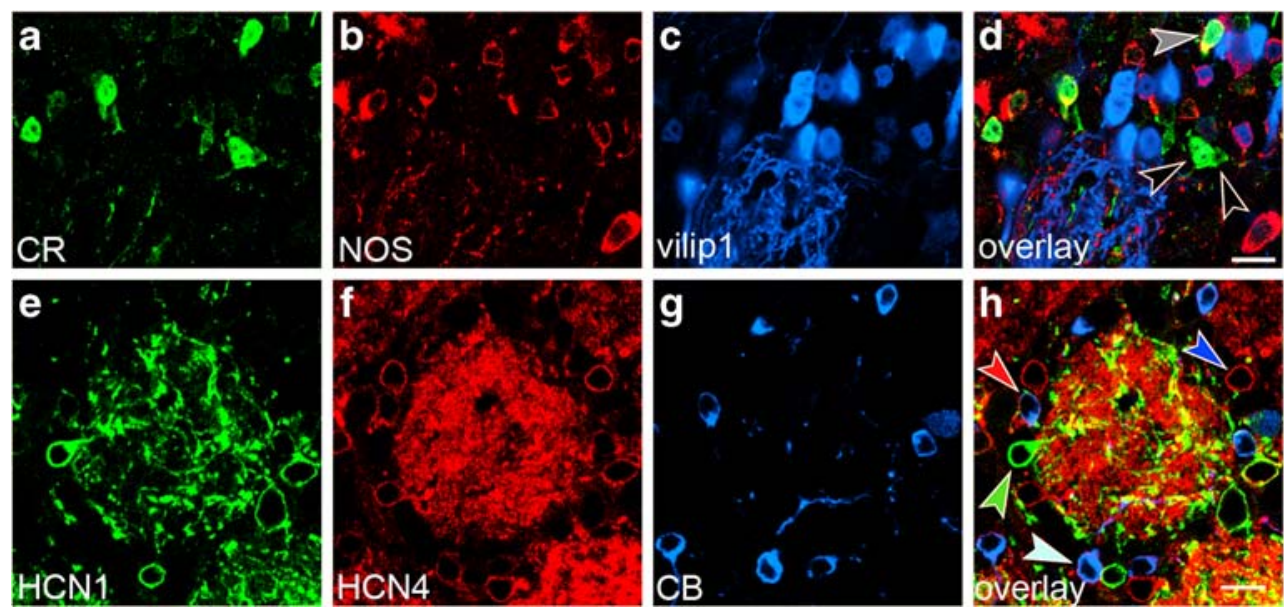

Fig. 3 Antibody staining in PG-like cell populations. a-d Example of marker staining (green $\mathrm{CR}$, red NOS, blue vilip1), which partially overlaps in PG-like cells (arrowheads). Antibodies used were: CAL, NOSmono, and vilip1. e-h Different co-localizations of $\mathrm{HCN}$ isoforms (green $\mathrm{HCN} 1$, red $\mathrm{HCN} 4$ ) and marker staining (blue $\mathrm{CB}$ )

in PG-like cells (arrowheads). Antibodies used were: HCN1 $\alpha$, PG2$1 \mathrm{~A} 4$, and CabPneu. Further staining is shown in Electronic Supplementary Material, Fig. 4. All staining patterns are summarized in Table 2. Color codes of arrowheads as in Table 2. Bars $10 \mu \mathrm{m}$ 


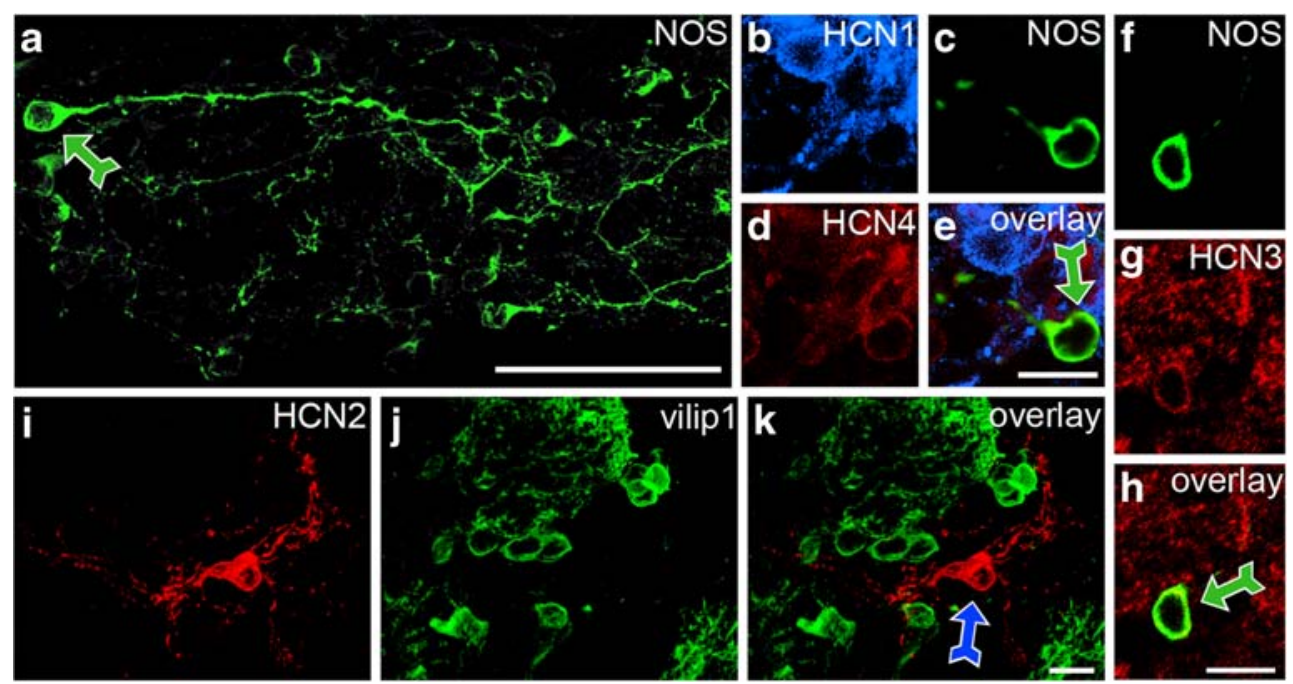

Fig. 4 Antibody staining in two SA-like cell populations. a-h Immunohistochemical identification of SA-like cells with IF10. Cells with IF10 (green barred arrow) are characterized by the co-localization of HCN1, $\mathrm{HCN} 3, \mathrm{HCN} 4$, and NOS. a A cell with IF10 is labeled by antibodies directed against NOS (NOSpoly). A long $(>100 \mu \mathrm{m})$ dendrite is visible. b-e Triple-staining for HCN1 (blue HCN1 $\alpha$ ), NOS (green NOSpoly), and HCN4 (red PG2-1A4). Cells with IF10 show strong expression of NOS, weaker expression of $\mathrm{HCN} 4$, and expression around the detection threshold of HCN1. $\mathbf{f}-\mathbf{h}$ Double-staining for NOS (green NOSpoly) and HCN3 (red HCN3 Shigemoto). i-k Immunohistochemical identification of cells with IF11 (blue barred arrow). These cells express HCN2 (red QQA-1A6). Projection of a confocal LSM section series reveals that dendrites of cells with IF11 do not reach into glomeruli. Glomeruli are visible because of the ramification of vilip1-stained PG-like cells (green vilip1) within glomeruli. Color codes of barred arrows as in Table 2. Bars $10 \mu \mathrm{m}(\mathbf{e}, \mathbf{h}, \mathbf{k}), 50 \mu \mathrm{m}(\mathbf{a})$ not stained (independent observers classified these cells as PG-like or SA-like). Based on the soma size alone, these cells might represent SA cells or large PG cells (for a comparison, see Table 3). However, whereas PG cells usually had one or two dendrites that ramified within glomeruli, cells with IF11 had more than three dendrites that could not be traced into glomeruli but rather seemed to surround them (Fig. 4i-k). Therefore, we suggest classifying these cells as SA-like cells. A detailed description of IFs found in SA-like cells is given in the Electronic Supplementary Material.

We observed TH-positive cells at the border to the EPL; these probably corresponded to SA cells recognized previously (Kosaka et al. 1998). Within the GL, these cells could not be distinguished unequivocally from the large number of TH-expressing juxtaglomerular cells and, therefore, were not further analyzed.

ET-like cells Six different IFs were identified in ET-like cells (Fig. 5, Electronic Supplementary Material, Fig. 5). IF12-IF15 represented different combinations of staining for $\mathrm{HCN}$ isoforms, whereas IF16 and IF17 were virtually devoid of HCN channel staining. IF12-IF15 contained staining for CCK but differed in their staining for HCN1, HCN4, NOS, vilip1, and hippo (Table 2, Fig. 5a-d, Electronic Supplementary Material, Fig. 5). IF12 featured staining with HCN1, HCN3, and HCN4 antibodies. In IF13 and IF15, HCN3 was found together with HCN4, whereas in IF14, HCN3 was present with HCN1 (Electronic Supple- mentary Material, Fig. 5). Cells with IF12, IF13, and IF15 possessed lateral dendrites (Table 3).

IF16 and IF17 featured staining with antibodies directed against $\mathrm{TH}$ (Fig. 5e-1). Co-localization of CCK and TH was never observed. IF16 contained NOS staining, whereas IF17 was devoid of it. No lateral dendrites were identified in cells with TH staining. A detailed description of IFs found in ET-like cells is given in the Electronic Supplementary Material.

Summary The combination of classical markers and HCN channel antibodies allowed us to identify cell populations that show one of at least 17 IFs. Four cell populations expressed only a single $\mathrm{HCN}$ isoform, two cell populations were stained by $\mathrm{HCN}$ antibodies only, six cell populations co-expressed several HCN channel isoforms, and five cell populations lacked HCN channels.

Frequency and soma size of populations of juxtaglomerular cells

For a full characterization of the immunohistochemically different cell populations in the GL, we estimated their frequency per glomerulus (see Materials and methods) and related it to the total number of cells per glomerulus as visualized by TOPRO-3, a dye that intercalates into the DNA of all cells (Table 3 ). 
Fig. 5 Antibody staining in ETlike cell populations within the GL. a-d Example of ET-like cells (arrows) expressing HCN1 channels (green $\mathrm{HCN} 1 \alpha$ ) and CCK (red CCK). Some of the $\mathrm{HCN} 1-$ and CCK-expressing cells (orange arrows) are also immunostained by antibodies directed against vilip1 (blue vilip1). e-I All TH-positive (green) ET-like cells (arrows) express hippo (red). Two representative examples are shown (e-h, $\mathbf{i}-\mathbf{l})$. TH-positive ET-like cells are either faintly stained (g) by NOS antibodies (blue) or devoid of NOS staining (k). Note the pronounced thick primary tuft in the ET-like cells. Antibodies used in $\mathbf{e}-\mathbf{l}$ were: hippo, NOSgt, and TH. Further staining is shown in Electronic Supplementary Material, Fig. 5. All staining patterns are summarized in Table 2. Color codes of arrows as in Table 2. Bars $10 \mu \mathrm{m}$
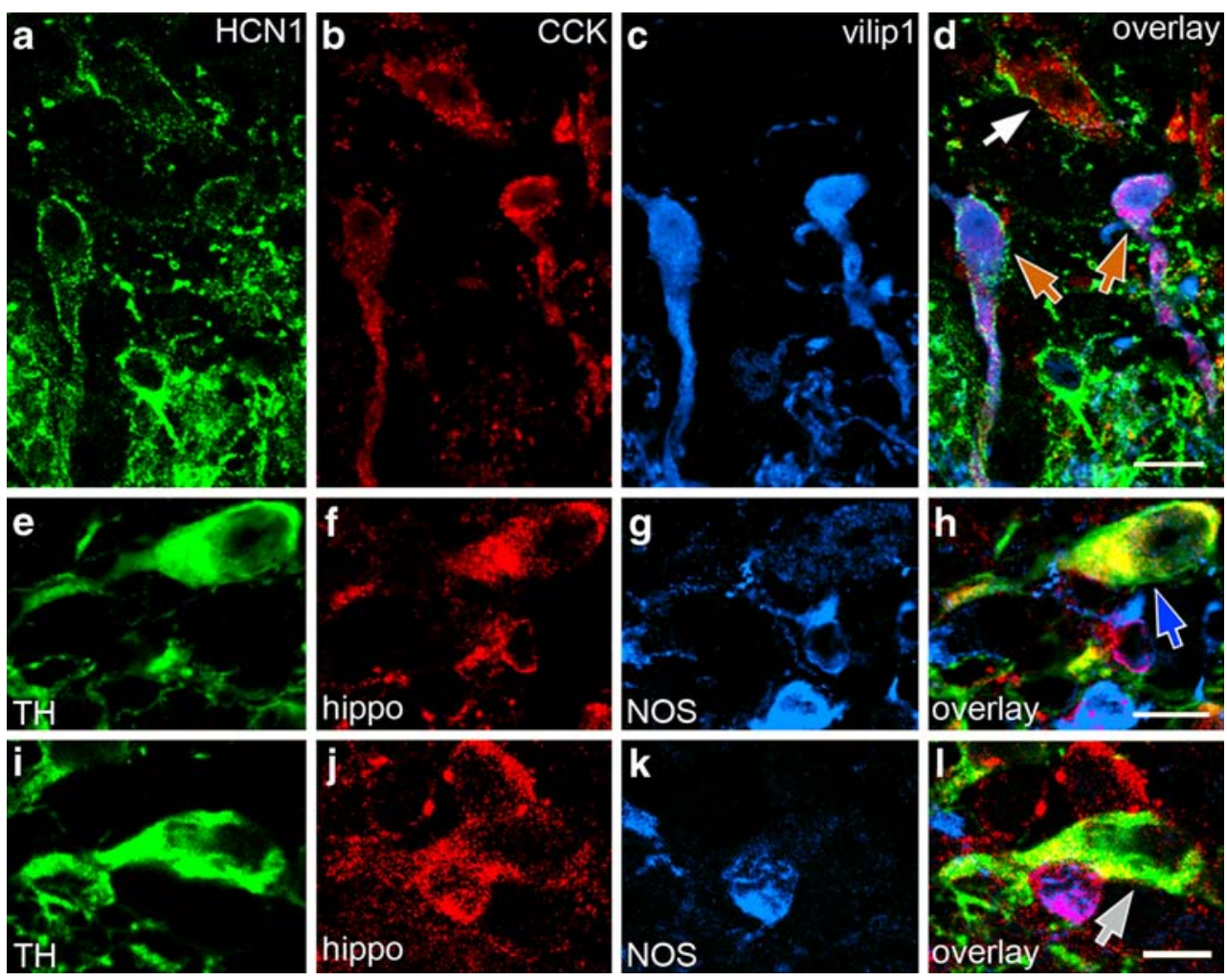

We counted cells across 81 adjacent glomeruli in three animals and estimated a total of $705 \pm 136$ cells per glomerulus, in good agreement with an analysis by Parrish-Aungst et al. (2007) who recorded $\sim 680$ cells per glomerulus. On average, $40 \%$ of cells in the GL were PG cells ( $267 \pm 25$ cells per glomerulus), as determined by counting cells across at least 121 adjacent glomeruli per PG-like cell population in at least three animals (see Materials and methods). SA-like cells and ET-like cells represented only $1 \%$ and $5 \%$ of cells, respectively: $9 \pm 1$ SA-like cells per glomerulus $(\geq 343$ adjacent glomeruli in $\geq 3$ animals per cell population), and $32 \pm 6$ ET-like cells per glomerulus ( $\geq 138$ adjacent glomeruli in $\geq 3$ animals per cell population).

The estimate critically depended on whether all juxtaglomerular cell populations were identified. To estimate the fraction of juxtaglomerular cells that escaped staining, we compared, in the same section, the number of immunohistochemically labeled cells with the number of TOPRO-3stained cells. The combination of antibodies directed against TH, NOS, CB, vilip1, CR, HCN1, HCN2, and HCN4 was sufficient to stain all juxtaglomerular cell populations identified in this study (see Table 2). GFAP staining was used to distinguish glia cells from neurons. The majority of glia cells in the GL are GFAP-positive astrocytes (Bailey and Shipley 1993; Kimelberg 2004). None of the staining for markers or $\mathrm{HCN}$ channels co-localized with the GFAP staining.
If many antibodies are combined and visualized by using secondary antibodies conjugated to the same dye, the equivalent detection of strong and weak staining is difficult. Thus, weakly stained cells may escape detection. To circumvent this problem, we visualized strongly and weakly staining antibodies with different dyes and adjusted detection settings to match the staining intensity. In combined TOPRO-3 and antibody staining (Fig. 6), we counted cells across 51 adjacent glomeruli (two animals) and identified $2.9 \%$ cells not labeled by the antibody mixture. The majority of these cells $(2 \%)$ were positioned at the border to the AL or EPL, probably representing cells of the $\mathrm{AL}$ and EPL rather than those of the GL. The few cells in the GL not labeled by antibodies $(0.9 \%)$ may have represented GFAP-negative glia cells (Kimelberg 2004). When one of the nine antibodies was omitted, the number of unstained cells was significantly enhanced (data not shown). Together, these results demonstrate that the vast majority, possibly even all, of the juxtaglomerular cells have been stained by our markers.

Populations of juxtaglomerular cells not only differed in IFs, but also in their morphology. Significant differences in the soma size of populations of PG-like cells were apparent, in agreement with previous reports (e.g., Kosaka and Kosaka 2007b; Parrish-Aungst et al. 2007; Pinching and Powell 1971; Qin et al. 2005).

To quantify the soma size, we determined the apparent cell diameter from the measured circumference (Table 3). 

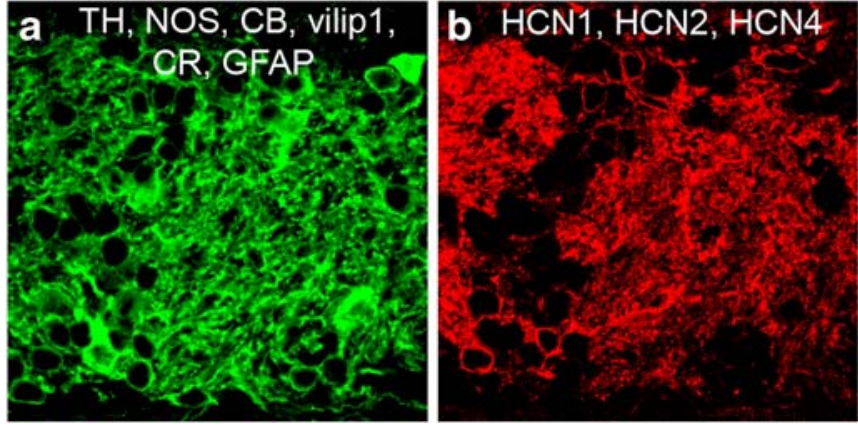

Fig. 6 Do our antibodies label all populations of juxtaglomerular cells? Practically all juxtaglomerular cells have been stained with at least one of the antibodies against (a) markers (green TH, NOS, CB, vilip1, CR, GFAP) or (b) HCN channels (red HCN1, HCN2, HCN4). c Nuclei are stained by TOPRO-3 (blue). d Overlay of a-c. Confocal

Mean diameters of PG-like cells (IF1-IF9) were between $6.5 \mu \mathrm{m}$ and $9.1 \mu \mathrm{m}$; most diameters were ca. $8 \mu \mathrm{m}$. By pair-wise Kruskal-Wallis tests with all possible combinations of mean diameters, we observed that most diameters of these PG-like cells were statistically different from those of other PG-, SA-, and ET-like cells: 94 of 108 possible pair-wise combinations between different PG-like cells, PG-like and SA-like cells, and PG-like and ET-like cells had a $P$-value well below 0.001 . However, cells with the IF7 and IF8 $(P=0.98)$ and cells with the IF2, IF6, and IF9 $(P>0.76)$ had similar diameters. The soma diameters of the two SA-like populations were similar (cells with IF10: 9.4 $\pm 1.1 \mu \mathrm{m}$; cells with IF11: $8.9 \pm 0.7 \mu \mathrm{m}$ ), although this difference was statistically significant $(P=0.035)$. ET-like cells had soma diameters ranging from $11.6 \mu \mathrm{m}$ to $12.6 \mu \mathrm{m}$. Pair-wise comparisons of cells with IF12/IF17 and IF13/IF16 showed similar diameters $(P>0.76)$. Cells with IF14 and IF16 differed in their somatic diameters $(P<0.02)$; all other possible comparisons of ET-like cell diameters were neither statistically different nor statistically similar $(0.1<P<0.65)$. Soma diameters resembled the diameters of PG, SA, and ET cells as described in classical Golgi-impregnated studies (Pinching and Powell 1971).

\section{Discussion}

HCN channels in juxtaglomerular cells

Using a comprehensive set of antibodies, including antibodies against all four HCN channel isoforms, we have conducted a systematic analysis of the glomerular layer. All four HCN isoforms are abundantly expressed in the olfactory bulb of mice. Many different combinations of $\mathrm{HCN}$ isoform co-localization in juxtaglomerular cells have been found. In our attempt to relate HCN channel expression
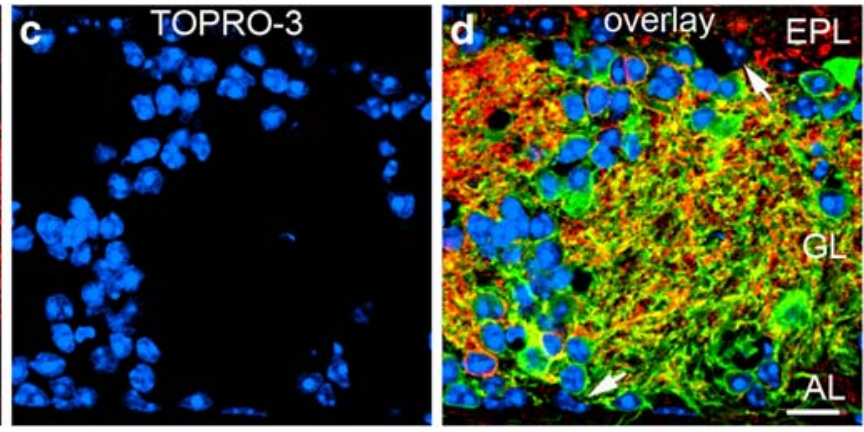

LSM sections rarely show unstained cells (arrows). Note: most unstained cells are positioned at the borders of the GL. Antibodies used: TH, CabPneu, NOSpoly, vilip1, CAL, PG2-1A4, QQA-1A6, HCN1 $\alpha$, and GFAP (EPL external plexiform layer, $G L$ glomerular layer, $A L$ olfactory nerve layer). $B a r 10 \mu \mathrm{m}$

patterns to previously described cell types, we have identified at least $17 \mathrm{IFs}$. In twelve of these IF, we have detected HCN channels. Two cell populations have probably been identified for the first time, because they are stained by HCN antibodies, but not by other markers (IF2 and IF11).

In some IFs, the intensity of marker and HCN stainings appears to be variable. This might reflect the presence of more than 17 cell populations. For example, evidence exists that IF7, IF8, and IF9 can be divided further on the basis of the differential expression of glutamic acid decarboxylase 65 (GAD65) and GAD67 in both TH- and CR-expressing cell types (Parrish-Aungst et al. 2007). In addition, activitydependent up- or down-regulation of expression levels could result in variable staining intensities. This has been suggested for TH- and NOS-expressing cell types (Brinon et al. 2001; Weruaga et al. 2000). Finally, regeneration of neurons is a prominent feature of the adult olfactory bulb. In the GL, PG cells that express $\mathrm{TH}, \mathrm{CR}, \mathrm{CB}$, or vilip1 have been shown to be constantly renewed (De Marchis et al. 2007). During maturation, these cells may express proteins at different levels; thus, the staining variability in some cell populations may result from the difference between developing and mature cells. However, for the following reasons, we favor the possibility that most IFs reflect the presence of different cell types, rather than only a few cell types with different levels of activity and/or different states of maturation: (1) marker staining and marker co-localization are highly reproducible, (2) the staining intensity for many markers does not show a large degree of variability but can be considered almost all-ornone, (3) none of the IFs appear to be clustered around individual, possibly activated glomeruli but are homogenously distributed among glomeruli.

Most of the previous studies of the olfactory bulb have been performed in rat. However, an important animal model for olfactory research is the mouse. This work and a few 
other recent studies have shown that the expression patterns of HCN channels and marker proteins are similar in the mouse and rat (Kosaka and Kosaka 2007b; Panzanelli et al. 2007; Parrish-Aungst et al. 2007; Notomi and Shigemoto 2004). For example, in mouse, HCN1 is strongly expressed in PG-like cells with IF1, which are positive for vilip1 and NOS, but negative for $\mathrm{CR}$ and TH. In rat, HCN1 is also found in PG cells that have not been tested for vilip1 or NOS but that are negative for CR and TH (Holderith et al. 2003). On the other hand, our results demonstrate that HCN4 is strongly and abundantly expressed in the mouse. This has not been described in the rat by Notomi and Shigemoto (2004) and may either reflect differences between the mouse and rat, the improvement of HCN4 antibodies, or the optimized staining procedures used in our analysis.

Based on their synaptic connectivity, PG cells fall into two groups. Type I cells, but not type II cells, seem to receive direct excitatory input from ORNs. The two groups were originally established by electron microscopy and immunogold staining with common marker antibodies for PG cells. TH and CCK staining has been found in PG cells of type I (Gutierrez-Mecinas et al. 2005; Kosaka et al. 1998; Kosaka and Kosaka 2007a), and CR, CB, and HCN1 have been found in PG cells of type II (Holderith et al. 2003; Kosaka et al. 1998; Kosaka and Kosaka 2007a). According to the expression of TH, CCK, CR, CB, and $\mathrm{HCN} 1$, we can assign our PG populations to either type I or II. Cells with IF3, IF4, and IF9 belong to type I, whereas cells with IF1, IF5, IF6, IF7, and IF8 belong to type II. Because no commonly used marker stains cells with IF2, they have escaped classification so far. IF10-IF17 have been found in SA- and ET-like cells and cannot be classified as type I or II, because this division is exclusively defined for PG cells.

Approximately 700 cells surround a standard glomerulus: about $40 \%$ are PG cells, $1 \%$ are SA cells, and $5 \%$ are ET cells. The rest of the cells (54\%) represent astrocytes, oligodendrocytes, microglia, and cells of the vasculature. We have not counted GFAP-positive astrocytes in the GL directly, because this is compromised by the location of GFAP in processes rather than in cell bodies (Bailey and Shipley 1993). Here, we have stained the vast majority (possibly all) juxtaglomerular cell populations. Thus, the ratio of identified-to-unidentified cell types should represent the neuron-to-glia ratio. We have calculated, on the basis of "numbers of cells per section of a glomerulus" (see Table 3), a ratio of $1.1 \pm 0.3$ neurons-to-glia cells. Because our frequency estimates of neuron populations are expected to be lower limits (see Materials and methods), the ratio of 1.1 is also expected to be a lower limit. The neuron-to-glia ratio in the GL is similar to the ratio in other layers of the brain (Roy et al. 2005). A previous estimation of the olfactory bulb has given a ratio of about 1.7 (ParrishAungst et al. 2007).
The frequencies of the cell populations reported here are similar to those described by other studies. For example, Panzanelli et al. (2007) have calculated that $44 \%, 16 \%$, and $14 \%$ of PG cells are CR-, TH-, and CB-positive, respectively. We have observed $50 \%, 11 \%$, and $11 \%$ of the respective PG cells. Parrish-Aungst et al. (2007) report that $10 \%, 27 \%, 10 \%, 0.4 \%$, and $11 \%$ of juxtaglomerular neurons are stained by antibodies against $\mathrm{CB}, \mathrm{CR}$, vilip1, PV, and TH, respectively. We have observed $10 \%, 43 \%, 19 \%, 4 \%$, and $13 \%$. Differences between our and published frequencies are probably attributable to different immunohistochemical procedures. Differences in the immunohistochemical procedure have been reported to affect the staining intensity of some of the antibodies used here and, thereby, influence frequency calculations (Kosaka and Kosaka 2007a).

\section{Functional implications of $\mathrm{HCN}$ channel expression}

An intriguing result is the prominent co-localization of HCN channel isoforms in juxtaglomerular cells. The coexpression of $\mathrm{HCN}$ isoforms is apparent in six of 17 identified fingerprints. If cases with $+/-\mathrm{HCN}$ staining intensity are included, co-expression is observed in 10 out of 17 identified fingerprints. Whether $\mathrm{HCN}$ channels form heteromeric complexes in vivo is still unknown. Although different HCN channel isoforms may co-localize without forming heteromers (Müller et al. 2003), heteromerization has been suggested to give rise to the functional diversity of HCN channels (Chen et al. 2001; Much et al. 2003; Ulens and Tytgat 2001). The composition and stoichiometry of HCN channel heteromers in neurons has rarely been analyzed (e.g., Whitaker et al. 2007). Likewise, the properties or physiological function of heteromeric $\mathrm{HCN}$ channels is not well understood (Chen et al. 2001; Ulens and Tytgat 2001; Whitaker et al. 2007). The large variety of expression patterns of $\mathrm{HCN}$ channels indicates the functional diversity of juxtaglomerular cells. For example, several juxtaglomerular cell types display intrinsic oscillatory activities (Antal et al. 2006; Hayar et al. 2004a, 2004b). Interestingly, all HCN-positive ET cell populations express more than one HCN isoform (IF12-IF15). Because about $60 \%$ of ET cells exhibit rhythmic bursts of action potentials (Antal et al. 2006; Hayar et al. 2004a, 2004b), and because cells with IF12-IF15 constitute about $70 \%$ of all ET cells, heteromeric $\mathrm{HCN}$ channels may be important for generating or modulating rhythmic activity. On the other hand, TH-expressing cells are also capable of generating rhythmic activity (Pignatelli et al. 2005). We have been unable to detect HCN channels in these cell types (IF9, IF16, and IF17); therefore, HCN channels are not the only channels involved in the generation of intrinsic rhythmic activity in the GL. Indeed, persistent sodium currents have been implicated in the generation of oscillations (Hayar et al. 2004a, 2004b; Pignatelli et al. 2005). 


\section{Concluding remarks}

Our results suggest that $\mathrm{HCN}$ channels play a key role in neuronal activity, e.g., in rhythmical bursts of action potentials. Moreover, the different expression patterns of HCN channels suggest a strong functional diversity of cell populations. A challenge for future work will be to define precisely, in quantitative terms, the diverse function of homomeric and heteromeric $\mathrm{HCN}$ channels in the nervous system, to identify the properties and physiological functions of the diverse cell types, and to establish a model of the sophisticated information processing that occurs in the olfactory bulb by taking its cellular and functional diversity into account.

Acknowledgements The authors are grateful to Dr. A. Mataruga and Dr. E. Kremmer for the generation of antibodies, to Dr. R. Shigemoto, Dr. K.-H. Braunewell, Dr. W.A. Gorczya, and CURE (Digestive Diseases Research Center) for the generous gift of antibodies, and to Dr. E. Kandel and Dr. M. Biel for the generous gift of HCN1 and HCN3 knockout animals. They also thank Dr. I. Gregor for his assistance with the statistical analysis. This work was supported by the Helmholtz Society.

Open Access This article is distributed under the terms of the Creative Commons Attribution Noncommercial License which permits any noncommercial use, distribution, and reproduction in any medium, provided the original author(s) and source are credited.

\section{References}

Adrian ED (1950) The electrical activity of the mammalian olfactory bulb. Electroencephalogr Clin Neurophysiol 2:377-388

Angelo K, London M, Christensen SR, Häusser M (2007) Local and global effects of $\mathrm{I}(\mathrm{h})$ distribution in dendrites of mammalian neurons. J Neurosci 27:8643-8653

Antal M, Eyre M, Finklea B, Nusser Z (2006) External tufted cells in the main olfactory bulb form two distinct subpopulations. Eur $\mathrm{J}$ Neurosci 24:1124-1136

Aungst JL, Heyward PM, Puche AC, Karnup SV, Hayar A, Szabo G, Shipley MT (2003) Centre-surround inhibition among olfactory bulb glomeruli. Nature 426:623-629

Bailey MS, Shipley MT (1993) Astrocyte subtypes in the rat olfactory bulb: morphological heterogeneity and differential laminar distribution. J Comp Neurol 328:501-526

Baker H, Kawano T, Margolis FL, Joh TH (1983) Transneuronal regulation of tyrosine hydroxylase expression in olfactory bulb of mouse and rat. J Neurosci 3:69-78

Bal T, McCormick DA (1997) Synchronized oscillations in the inferior olive are controlled by the hyperpolarization-activated cation current I(h). J Neurophysiol 77:3145-3156

Bastianelli E, Pochet R (1995) Calmodulin, calbindin-D28k, calretinin and neurocalcin in rat olfactory bulb during postnatal development. Brain Res Dev Brain Res 87:224-227

Bender RA, Galindo R, Mameli M, Gonzalez-Vega R, Valenzuela CF, Baram TZ (2005) Synchronized network activity in developing rat hippocampus involves regional hyperpolarization-activated cyclic nucleotide-gated $(\mathrm{HCN})$ channel function. Eur J Neurosci 22:2669-2674

Berger T, Larkum ME, Luscher HR (2001) High I(h) channel density in the distal apical dendrite of layer V pyramidal cells increases bidirectional attenuation of EPSPs. J Neurophysiol $85: 855-868$

Bernstein HG, Becker A, Keilhoff G, Spilker C, Gorczyca WA, Braunewell KH, Grecksch G (2003) Brain region-specific changes in the expression of calcium sensor proteins after repeated applications of ketamine to rats. Neurosci Lett 339:95-98

Bouilleret V, Loup F, Kiener T, Marescaux C, Fritschy JM (2000) Early loss of interneurons and delayed subunit-specific changes in GABA(A)-receptor expression in a mouse model of mesial temporal lobe epilepsy. Hippocampus 10:305-324

Brinon JG, Alonso JR, Arevalo R, Garcia-Ojeda E, Lara J, Aijon J (1992) Calbindin D-28k-positive neurons in the rat olfactory bulb. An immunohistochemical study. Cell Tissue Res 269:289-297

Brinon JG, Alonso JR, Garcia-Ojeda E, Crespo C, Arevalo R, Aijon J (1997) Calretinin- and parvalbumin-immunoreactive neurons in the rat main olfactory bulb do not express NADPH-diaphorase activity. J Chem Neuroanat 13:253-264

Brinon JG, Arevalo R, Crespo C, Bravo IG, Okazaki K, Hidaka H, Aijon J, Alonso JR (1998) Neurocalcin immunoreactivity in the rat main olfactory bulb. Brain Res 795:204-214

Brinon JG, Crespo C, Weruaga E, Martinez-Guijarro FJ, Aijon J, Alonso JR (2001) Bilateral olfactory deprivation reveals a selective noradrenergic regulatory input to the olfactory bulb. Neuroscience 102:1-10

Chen S, Wang J, Siegelbaum SA (2001) Properties of hyperpolarizationactivated pacemaker current defined by coassembly of HCN1 and HCN2 subunits and basal modulation by cyclic nucleotide. J Gen Physiol 117:491-504

Crespo C, Alonso JR, Brinon JG, Weruaga E, Porteros A, Arevalo R, Aijon J (1997) Calcium-binding proteins in the periglomerular region of typical and typical olfactory glomeruli. Brain Res 745:293-302

Day M, Carr DB, Ulrich S, Ilijic E, Tkatch T, Surmeier DJ (2005) Dendritic excitability of mouse frontal cortex pyramidal neurons is shaped by the interaction among $\mathrm{HCN}$, Kir2, and Kleak channels. J Neurosci 25:8776-8787

De Marchis S, Bovetti S, Carletti B, Hsieh YC, Garzotto D, Peretto P, Fasolo A, Puche AC, Rossi F (2007) Generation of distinct types of periglomerular olfactory bulb interneurons during development and in adult mice: implication for intrinsic properties of the subventricular zone progenitor population. J Neurosci 27:657-664

Feigenspan A, Teubner B, Willecke K, Weiler R (2001) Expression of neuronal connexin36 in AII amacrine cells of the mammalian retina. J Neurosci 21:230-239

Fletcher ML, Smith AM, Best AR, Wilson DA (2005) High-frequency oscillations are not necessary for simple olfactory discriminations in young rats. J Neurosci 25:792-798

Gierke P, Zhao C, Brackmann M, Linke B, Heinemann U, Braunewell $\mathrm{KH}$ (2004) Expression analysis of members of the neuronal calcium sensor protein family: combining bioinformatics and Western blot analysis. Biochem Biophys Res Commun 323:3843

Gutierrez-Mecinas M, Crespo C, Blasco-Ibanez JM, Gracia-Llanes FJ, Marques-Mari AI, Martinez-Guijarro FJ (2005) Characterization of somatostatin- and cholecystokinin-immunoreactive periglomerular cells in the rat olfactory bulb. J Comp Neurol 489:467-479

Hayar A, Karnup S, Ennis M, Shipley MT (2004a) External tufted cells: a major excitatory element that coordinates glomerular activity. J Neurosci 24:6676-6685

Hayar A, Karnup S, Shipley MT, Ennis M (2004b) Olfactory bulb glomeruli: external tufted cells intrinsically burst at theta frequency and are entrained by patterned olfactory input. J Neurosci 24:1190-1199

Holderith NB, Shigemoto R, Nusser Z (2003) Cell type-dependent expression of HCN1 in the main olfactory bulb. Eur J Neurosci $18: 344-354$ 
Kaupp UB, Seifert R (2001) Molecular diversity of pacemaker ion channels. Annu Rev Physiol 63:235-257

Kimelberg HK (2004) The problem of astrocyte identity. Neurochem Int 45:191-202

Kosaka K, Kosaka T (2007a) Chemical properties of type 1 and type 2 periglomerular cells in the mouse olfactory bulb are different from those in the rat olfactory bulb. Brain Res 1167:42-55

Kosaka T, Kosaka K (2007b) Heterogeneity of nitric oxide synthasecontaining neurons in the mouse main olfactory bulb. Neurosci Res $57: 165-178$

Kosaka K, Heizmann CW, Kosaka T (1994) Calcium-binding protein parvalbumin-immunoreactive neurons in the rat olfactory bulb. 1 . Distribution and structural features in adult rat. Exp Brain Res 99:191-204

Kosaka K, Toida K, Aika Y, Kosaka T (1998) How simple is the organization of the olfactory glomerulus? The heterogeneity of so-called periglomerular cells. Neurosci Res 30:101-110

Kosaka K, Toida K, Aika Y, Kosaka T (2008) Tyrosine hydroxylasepositive GABAergic juxtaglomerular neurons are the main source of the interglomerular connections in the mouse main olfactory bulb. Neurosci Res 60:349-354

Liu S, Shipley MT (2008) Multiple conductances cooperatively regulate spontaneous bursting in mouse olfactory bulb external tufted cells. J Neurosci 28:1625-1639

Liu WL, Shipley MT (1994) Intrabulbar associational system in the rat olfactory bulb comprises cholecystokinin-containing tufted cells that synapse onto the dendrites of GABAergic granule cells.J Comp Neurol 346:541-558

Ludwig A, Budde T, Stieber J, Moosmang S, Wahl C, Holthoff K, Langebartels A, Wotjak C, Munsch T, Zong X, Feil S, Feil R, Lancel M, Chien KR, Konnerth A, Pape HC, Biel M, Hofmann F (2003) Absence epilepsy and sinus dysrhythmia in mice lacking the pacemaker channel HCN2. EMBO J 22:216-224

Lüthi A, McCormick DA (1998a) H-current: properties of a neuronal and network pacemaker. Neuron 21:9-12

Lüthi A, McCormick DA (1998b) Periodicity of thalamic synchronized oscillations: the role of $\mathrm{Ca}^{2+}$-mediated upregulation of Ih. Neuron 20:553-563

Macrides F, Chorover SL (1972) Olfactory bulb units: activity correlated with inhalation cycles and odor quality. Science $175: 84-87$

Magee JC (1998) Dendritic hyperpolarization-activated currents modify the integrative properties of hippocampal CA1 pyramidal neurons. J Neurosci 18:7613-7624

Magee JC, Carruth M (1999) Dendritic voltage-gated ion channels regulate the action potential firing mode of hippocampal CA1 pyramidal neurons. J Neurophysiol 82:1895-1901

Margrie TW, Schaefer AT (2003) Theta oscillation coupled spike latencies yield computational vigour in a mammalian sensory system. J Physiol (Lond) 546:363-374

Mataruga A, Kremmer E, Müller F (2007) Type 3a and type 3b OFF cone bipolar cells provide for the alternative rod pathway in the mouse retina. J Comp Neurol 502:1123-1137

Much B, Wahl-Schott C, Zong X, Schneider A, Baumann L, Moosmang S, Ludwig A, Biel M (2003) Role of subunit heteromerization and N-linked glycosylation in the formation of functional hyperpolarization-activated cyclic nucleotide-gated channels. J Biol Chem 278:43781-43786

Müller F, Scholten A, Ivanova E, Haverkamp S, Kremmer E, Kaupp UB (2003) HCN channels are expressed differentially in retinal bipolar cells and concentrated at synaptic terminals. Eur J Neurosci 17:2084-2096

Nolan MF, Malleret G, Lee KH, Gibbs E, Dudman JT, Santoro B, Yin D, Thompson RF, Siegelbaum SA, Kandel ER, Morozov A (2003) The hyperpolarization-activated HCN1 channel is impor- tant for motor learning and neuronal integration by cerebellar Purkinje cells. Cell 115:551-564

Notomi T, Shigemoto R (2004) Immunohistochemical localization of Ih channel subunits, HCN1-4, in the rat brain. J Comp Neurol 471:241-276

Nusser Z, Kay LM, Laurent G, Homanics GE, Mody I (2001) Disruption of GABA(A) receptors on GABAergic interneurons leads to increased oscillatory power in the olfactory bulb network. J Neurophysiol 86:2823-2833

Panzanelli P, Fritschy JM, Yanagawa Y, Obata K, Sassoe-Pognetto M (2007) GABAergic phenotype of periglomerular cells in the rodent olfactory bulb. J Comp Neurol 502:990-1002

Parrish-Aungst S, Shipley MT, Erdelyi F, Szabo G, Puche AC (2007) Quantitative analysis of neuronal diversity in the mouse olfactory bulb. J Comp Neurol 501:825-836

Pignatelli A, Kobayashi K, Okano H, Belluzzi O (2005) Functional properties of dopaminergic neurones in the mouse olfactory bulb. J Physiol (Lond) 564:501-514

Pinching AJ, Powell TP (1971) The neuron types of the glomerular layer of the olfactory bulb. J Cell Sci 9:305-345

Pinching AJ, Powell TP (1972) Experimental studies on the axons intrinsic to the glomerular layer of the olfactory bulb. J Cell Sci 10:637-655

Qin ZP, Ye SM, Du JZ, Shen GY (2005) Postnatal developmental expression of calbindin, calretinin and parvalbumin in mouse main olfactory bulb. Acta Biochim Biophys Sin (Shanghai) 37:276-282

Roy TS, Sharma V, Seidler FJ, Slotkin TA (2005) Quantitative morphological assessment reveals neuronal and glial deficits in hippocampus after a brief subtoxic exposure to chlorpyrifos in neonatal rats. Brain Res Dev Brain Res 155:71-80

Royet JP, Souchier C, Jourdan F, Ploye H (1988) Morphometric study of the glomerular population in the mouse olfactory bulb: numerical density and size distribution along the rostrocaudal axis. J Comp Neurol 270:559-568

Santoro B, Chen S, Luthi A, Pavlidis P, Shumyatsky GP, Tibbs GR, Siegelbaum SA (2000) Molecular and functional heterogeneity of hyperpolarization-activated pacemaker channels in the mouse CNS. J Neurosci 20:5264-5275

Stieber J, Herrmann S, Feil S, Loster J, Feil R, Biel M, Hofmann F, Ludwig A (2003) The hyperpolarization-activated channel $\mathrm{HCN} 4$ is required for the generation of pacemaker action potentials in the embryonic heart. Proc Natl Acad Sci USA 100:15235-15240

Stieber J, Stockl G, Herrmann S, Hassfurth B, Hofmann F (2005) Functional expression of the human HCN3 channel. J Biol Chem 280:34635-34643

Stopfer M, Laurent G (1999) Short-term memory in olfactory network dynamics. Nature 402:664-668

Ulens C, Tytgat J (2001) Functional heteromerization of HCN1 and HCN2 pacemaker channels. J Biol Chem 276:6069-6072

Vardi N, Zhang LL, Payne JA, Sterling P (2000) Evidence that different cation chloride cotransporters in retinal neurons allow opposite responses to GABA. J Neurosci 20:7657-7663

Wachowiak M, Shipley MT (2006) Coding and synaptic processing of sensory information in the glomerular layer of the olfactory bulb. Semin Cell Dev Biol 17:411-423

Walsh RR (1956) Single cell spike activity in the olfactory bulb. Am J Physiol 186:255-257

Weruaga E, Brinon JG, Porteros A, Arevalo R, Aijon J, Alonso JR (2000) Expression of neuronal nitric oxide synthase/NADPHdiaphorase during olfactory deafferentation and regeneration. Eur J Neurosci 12:1177-1193

Whitaker GM, Angoli D, Nazzari H, Shigemoto R, Accili EA (2007) $\mathrm{HCN} 2$ and HCN4 isoforms self-assemble and co-assemble with equal preference to form functional pacemaker channels. J Biol Chem 282:22900-22909 